Balkan Araştırma Enstitüsü Dergisi / Journal of Balkan Research Institute Cilt/Volume 8, Say1/Number 2, Aralık/December 2019, ss. 295-332.

DOI: 10.30903/Balkan.657748

ARAȘTIRMA MAKALESİ - RESEARCH ARTICLE

\title{
KATOLİK BİR OSMANLI BÜROKRATI VE ARNAVUT MILLIYETÇİSI PAŞKO VASA PAŞA (1825-1892)
}

Said OLGUN*

öz

İşkodralı Katolik bir Arnavut olan Vasa Paşa, Tanzimat ve II. Abdülhamid döneminin önemli bürokratlarından biridir. Roma ve Venedik'te eğitim almış bir polyglot olarak, kariyerine Babıâli Tercüme Odası'nda başlamıştır. Yaşadığı dönem açısından Osmanlı Devleti'nin arka arkaya birçok problemle karşılaştığı Rumeli coğrafyasında çeşitli görevlerde bulunmuştur. Kariyerinin en yüksek noktasına Paşa unvanıyla Cebel-i Lübnan Mutasarrıflığına atanmasıyla ulaşmıştır. Vefatına değin dokuz yıl kesintisiz bir şekilde bu görevini sürdürmüştür. Vasa Paşa, kırk yıldan uzun bir süre üst düzey devlet memuriyetinde bulunmuştur. Bu süre içerisinde bir yandan şaşmaz bir sadakatle devlete hizmet ederken bir yandan da yabancı dillerde kaleme aldığı eserleriyle Arnavut dili, tarihi, kültürü ve edebiyatına çok önemli katkılar sağlamıştır. Söz konusu eserleriyle daha çok Avrupa kamuoyunun dikkatini Arnavutlar ve Arnavutluk üzerine çekmeye çalışmıştır. Faaliyetleri ve eserleriyle Arnavut milliyetçiliğinin önde gelen isimlerinden biri olarak kabul edilir. $\mathrm{Bu}$ çalışmada Osmanlı devlet adamı kimliğinin yanı sıra Arnavut milliyetçisi kimliğiyle tanınan Vasa Paşa'nın hayatı, memuriyeti, Arnavut milliyetçiliğine yönelik faaliyetleri ile eserleri üzerinde durulmuştur.

Anahtar Kelimeler: Paşko Vasa Paşa, İşkodra, Cebel-i Lübnan, Arnavutluk, Arnavut Milliyetçiliği

\footnotetext{
* Dr. Öğr. Üyesi, Siirt Üniversitesi, Fen-Edebiyat Fakültesi, Tarih Bölümü, Siirt, ORCID: orcid.org/0000-0002-9171-2788, E-mektup: saidolgun@ @otmail.com
} 


\title{
SAİD OLGUN
}

\section{A CATHOLIC OTTOMAN BUREAUCRAT AND AN ALBANIAN NATIONALIST PASHKO WASSA PASHA (1825-1892)}

\begin{abstract}
Wassa Pasha, a Catholic Albanian from Shkodra, was an important civil servant in the Tanzimat period in the reign of Abdul Hamid II. A polyglot who was educated in Rome and Venice, Wassa Pasha started his career in the Translation Office of the Sublime Porte, and served in various capacities in Rumelia, where the Ottoman Empire was at the time facing one problem after another. The high point of his career was his appointment as Governor of Mount Lebanon with the title of Pasha - a position in which he served for nine consecutive years until his death. Wassa Pasha was a high-level civil servant for more than 40 years, during which he served the state with unwavering loyalty, and made important contributions to the Albanian language, history, culture and literature with the foreign language books he wrote. In his books, he sought to draw the attention of the European public to Albania and the Albanian people, and as a result of his works and activities, he is still considered a leading figure in Albanian nationalism. This study discusses the life, career and Albanian nationalist activities of Wassa Pasha, who was known both as an Ottoman statesman and an Albanian nationalist.
\end{abstract}

Keywords: Pashko Wassa Pasha, Shkodra, Mount Lebanon, Albania, Albanian Nationalism

\section{Giriş}

XIX. yüzyıl, Osmanlı Devleti'nin başta siyasî, sosyal, iktisadi ve kültürel olmak üzere hemen bütün alanlarda hızlı değişim ve dönüşümler yaşadığı bir dönem olmuştur. 1804 Sırp İsyanı ile başlayıp 1821 Mora İsyanı ile devam eden milliyetçi ayaklanmalar, devlet mekanizması içerisinde uzun yıllardır devam edegelen birçok teamülün ve uygulamanın değişimine sebep olmuştur. 1821 İsyanı ve arkasından bağımsız bir Yunan devletinin kurulması, Osmanlı idaresini oldukça endişelendirirken imparatorluğun parçalanmasının önüne geçmek isteyen devlet adamları, yeni bir organizasyon ve batılılaşma hareketi başlatmışlardır. Bu çerçevede batılı devlet anlayışının siyasal modelinden unsurlar benimsemeye ve uyarlamaya yöneldiklerinde eşitlik sorunuyla karşı karşıya gelmişlerdir. Osmanlı devlet 


\section{KATOLIKK BİR OSMANLI BÜROKRATI VE ARNAVUT MILLLIYETÇİSI PAŞKO VASA \\ PAŞA (1852-1892)}

adamları, "ayrılıkçı-milliyetçi" tehdidi etkisiz hale getirebilmek için "eşitlikçi politikayı cazip kılacak" bir Osmanlıcılık kavramı geliştirmişlerdir. ${ }^{1}$

Osmanlıc1lı düşüncesinin etkisiyle Tanzimat Döneminde gerçekleştirilen reformlarla din farkl1lığ gözetmeksizin bir sadakat bilinci oluşturulmaya çalışılmıştır. Osmanlılık, neredeyse millî bir kimlik olarak benimsenirken, seküler bir bürokratik elitin doğmasına yardım etmiştir. Her ne kadar devlet İslam devleti olma özelliğini sürdürüyor olsa da klasik "yöneten-yönetilen" farklı1ığı yavaş yavaş ortadan kalkmaya başlamıştır. Kırmızı'ya göre "bu değişimin kaynağında imparatorluk teb 'ası arasında ortaya çıkan milliyetçi akımlara karşı çare olarak milliyetçilik-üstü bir akım oluşturma gayretlerinin yanı sıra, Batılı güçlerin verdikleri desteklerin bir bedeli olarak kurdukları baskı..." yatmaktadır. ${ }^{2}$

Yukarıda bahsedilen bu dönüşümün tipik örneklerinden birisi olarak karşımıza çıkan isim Paşko Vasa Paşa'dır. 1821 yılında Divan-1 Hümayun tercümanlığı görevinden Rumların uzaklaştırılarak yerine Tercüme Odası'nın kurulması bununla birlikte Tanzimat döneminin oluşturduğu Osmanlılık kimliğine bağlı olarak seküler bir bürokratik kimliğin ortaya çıkması Katolik bir Arnavut olan Vasa'nın Tercüme Odası'nda başlayan memuriyet kariyerinin Cebel-i Lübnan Mutasarrıflığına değin uzanmasını sağlamıştır. Tipik bir Tanzimat dönemi Osmanlı bürokratı olarak nitelendirilebilecek olan Vasa, memuriyeti boyunca bir yandan devlete sadakatle hizmet ederken bir yandan da çalışmalarıyla ve faaliyetleriyle Arnavut ulusal kimliğinin inşası sürecine yadsınamaz katkılarda bulunmuştur.

Yapılan bu çalışmanın temel amacı hem Türk hem de yabancı tarih yazınında Arnavut milliyetçiliğinin önemli isimlerinden biri olarak kabul edilen Vasa'nın hayat1, memuriyeti, eserleri ve faaliyetleri hakkında bilgi vermektir. Bu yönüyle çalışmanın Osmanlı kimliğinin yanı sıra Katolik Arnavut kimliğine de sahip olan bir Osmanlı bürokratının düşünce dünyasının anlaşılmasına katkı sağlayacağı düşünülmektedir. Esasen bir yandan Osmanlı kimliğiyle devletin ve milletin âli menfaatleri için mücadele ederken bir yandan da mensubu bulunduğu Arnavutların ulusal kimliklerinin inşası sürecinde nasıl bir rol üstlendiğini ve bu durumun bir çelişki değil imparatorluk bünyesinde yaşamanın doğal bir sonucu olduğunu ortaya

\footnotetext{
1 Abdülhamit Kırmızı, II. Abdülhamit Dönemi (1876-1909) Osmanlı Bürokrasisinde Gayrimüslimler, Hacettepe Üniversitesi Sosyal Bilimler Enstitüsü Yayımlanmamış Yüksek Lisans Tezi, Danışman: Prof. Dr. Bahattin Yediyıldız, Ankara 1998, s. 7-8.

${ }^{2}$ Kirmız1, a.g.t., s. 9.
} 


\section{SAİD OLGUN}

koymak da çalışmanın amaçlarından biridir. İstifade edilen telif eserler ile yoğun bir şekilde kullanılan özgün arşiv malzemesi ve süreli yayınlar, Vasa'nın hayatının çok bilinmeyen ayrıntılarının ortaya konulmasını sağlamıştır.

\section{Doğumu, Ailesi ve Eğitimi}

17 Eylül 1825 'te bugünkü Arnavutluk'un kuzey kesiminde yer alan İşkodra'da doğmuştur. ${ }^{3}$ Mirdit kabilesine mensup ${ }^{4}$ Sayel Vasa'nın oğlu olan Paşko Vasa, Katolik bir Hristiyan'd1. ${ }^{5}$ Venedik ve Roma'daki eğitimi esnasında coğrafya, tarih, hesap, servet, hikmet ve hukuk dersleri almıştır. ${ }^{6}$

1842-1847 yılları arasında İșkodra'da bulunan İngiliz Konsolosluğu'nda çalışmış bu sırada İtalyanca, Fransızca, Türkçe ve Yunancasını ilerletme imkânı bulmuştur. ${ }^{7} 1848$ İhtilallerinin yaşandığı dönemde İtalya'da bulunmuş, ${ }^{8}$ zamanının çoğunu dil ve edebiyat çalışmalarına ayırmıştır. ${ }^{9}$ Bu dönemde kilise karşıtı bir Cumhuriyetçi olan Vasa, 4 Mayis 1849 'da Marghera'da Venedikliler tarafindan Avusturya'ya karşı başlatılan bir ayaklanmada yer almıştır. 28 Ağustos 1849' da Avusturya birliklerinin bölgeye gelmesi üzerine Ancona'ya kaçmak zorunda kalmış; yakalandıktan sonra Osmanlı vatandaşı olması nedeniyle İstanbul'a gönderilmiştir. ${ }^{10}$

Vasa, Arnavutçanın yanı sıra ileri düzeyde Türkçe, Fransızca, İngilizce, İtalyanca, Rumca ve Slavcanın yanında ileri seviyede olmasa da Bulgarca ve Arapça da biliyordu. ${ }^{11}$

\footnotetext{
${ }^{3}$ Robert Elsie, Historical Dictionary of Albania, The Scarecrow Press, Lanham 2010, s. 465.

${ }^{4}$ Engin Deniz Akarl1, The Long Peace: Ottoman Lebanon 1861-1920, University of California Press, California 1993, s. 195.

5 Devlet Arşivleri Başkanlığı Osmanlı Arşivi (BOA), Dahiliye Nezâreti Sicill-i Ahval Komisyonu Defterleri (DH.SAID.d), 1/236, Hicri (H.) 29.12.1241 (4 Ağustos 1826). Abdülhamit Kırmızı, Vasa'nın baba adını Mişel olarak vermektedir. Vasa'nın oğullarından birinin Michel adında olması göz önünde bulundurulduğunda baba adının Mişel olma ihtimali oldukça yüksektir. Kırmızı, a.g.e., s. 67.

${ }^{6}$ BOA, DH.SAID.d, 1/236, 29.12.1241 (4 Ağustos 1826).

${ }^{7}$ Robert Elsie, Albanian Literature: A Short History, I. B. Tauris, New York 2005, s. 80.

${ }^{8}$ Elsie, Historical Dictionary of Albania, s. 465.

${ }^{9}$ Akarli, a.g.e., s. 195.

${ }^{10}$ Elsie, Albanian Literature: A Short History, s. 81

${ }^{11}$ BOA, DH.SAID.d, 1/236, H. 29.12.1241 (4 Ağustos 1826).
} 


\section{KATOLIKK BİR OSMANLI BÜROKRATI VE ARNAVUT MILLLIYETÇİSI PAŞKO VASA \\ PAŞA (1852-1892)}

\section{2. İstanbul'a Gelişi ve İlk Memuriyetleri}

Yirmili yaşlarının başında imparatorluğun başkenti İstanbul'a gelen Vasa, edebî çevrelerin içerisinde yer almış yazınsal faaliyetlerini sürdürerek Türkçesini ilerletmiştir. ${ }^{12}$ Payitahtta bulunduğu ilk zamanlarda yaşadığı maddî sıkıntılardan sonra ${ }^{13}$ yoğun uğraşlar neticesinde öğrendiği yabanc1 dillerin sağladığı bir avantajla 1850 yılında Babıâli Tercüme Odası'nda ücretsiz olarak çalışmaya başlamıştır. Bürokraside yükselmek isteyen genç kalemiye efendileri için arzu edilen bir işe dönüşen Tercüme Odası'nda görev yapmak, ${ }^{14}$ Vasa'ya devlet kapısının ardına kadar açılmasını sağlamış olmalıdır. Bir sene kadar burada çalışan Vasa, 1851 yılında 500 kuruş maaşla Sihıyye Dairesi Tercümanlığına atanmıştır. ${ }^{15} \mathrm{Bu}$ dönemde bir müddet Londra' daki Osmanlı elçiliğinde görev yapmıştır. ${ }^{16}$

\section{3. İşkodra Vilayeti Hükümet Tercümanlığından Cebel-i Lübnan Mutasarrıflığına Kadar Memuriyeti}

Vasa Efendi, Nisan 1855'te İşkodra Valiliğine atanan Agâh Abdülaziz Paşa'nın maiyetinde onun tercümanı olarak İşkodra'ya gitmiştir. $\mathrm{Bu}$ görevi, yaklaşık on yıldır gitmediği memleketini yeniden görmek arzusuyla kabul etmiş bir daha İşkodra'dan ayrılmak istemediği için İşkodra Vilayet Tercümanı olarak görevlendirilmesi talebinde bulunmaktan geri durmamıştır. 23 Ekim 1855 tarihinde bu talepte bulunmuşsa da isteğinin gerçekleşmesi iki yıldan daha uzun bir süre almıştır. ${ }^{17}$

Arnavutluk'un önemli şehirlerinden biri olan İşkodra'da bu dönemde müstakil bir hükümet tercümanı bulunmuyordu. Doğrudan doğruya hükümete bağlı bir tercümanın bulunmaması bölgede bulunan konsoloslar ve yabancı tüccarlarla iletişim kurulmasında birtakım zorluklara sebebiyet vermekteydi. Çoğu zaman yapılacak herhangi bir görüşme ve yazışma için şehirde yabanc1 dil bilen insan arayışına giren yerel hükümet, yaşanan bu müşkülata bir son vermek amacıyla müstakil bir tercümanın görevlendirilmesi için merkezî hükümet nezdinde girişimlerde bulunmaya başlamıştır. Nihayet ileri düzeyde

\footnotetext{
${ }^{12}$ Akarli, a.g.e., s. 196.

${ }^{13}$ Elsie, Historical Dictionary of Albania, s. 465.

${ }^{14}$ Carter V. Findley, Osmanlı Imparatorluğu'nda Bürokratik Reform Babıâli, 1789-1922, çev. Ercan Ertürk, Tarih Vakfi Yurt Yayınları, İstanbul 2014, s. 158.

${ }^{15}$ BOA, DH.SAID.d, 1/236, H. 29.12.1241 (4 Ağustos 1826).

${ }^{16}$ Elsie, Albanian Literature: A Short History, s. 81.

${ }^{17}$ BOA, Hariciye Nezâreti Tercüme Odası Belgeleri (HR.TO), 421/19.
} 


\section{SAID OLGUN}

İtalyanca ve Fransızca bilmesine ek olarak daha önce tercümanlık görevinde bulunması nedeniyle İşkodra'lı Vasa'nın tercüman olarak görevlendirilmesine karar verilmiştir. ${ }^{18}$

1857 yılının Kasım ayından itibaren aylık 1000 kuruş maaş ile İşkodra Vilayeti Hükümet Tercümanlığ 1 görevine başlayan Vasa, ${ }^{19}$ "hüsn-i hidmet ve hareketi" nedeniyle hükümet tarafindan takdir edilmiştir. ${ }^{20}$ Öyle ki merkezî hükümet, yerel hükümete görevine bu şekilde devam ettiği müddetçe gerekli hürmetin gösterilmesini tembih etmekten geri durmamıştır. ${ }^{21} \mathrm{Hem}$ yapmış olduğu hizmetlerinin hem de sadakatinin bir sonucu olarak 1859 yılının Haziran ayında yapılan 500 kuruş zamla maaşı 1500 kuruşa çıkartılmıştır. ${ }^{22}$

1859 y1lında İşkodra'daki Katolikler tarafından Meclis-i İdare Azalığına seçilen Vasa, tercümanlık göreviyle birlikte azalık görevini de sürdürmüştür. ${ }^{23}$

Vasa, İşkodra'nın Karadağ ile sınır olması nedeniyle zaman zaman çeşitli görevlerle Karadağ'a gönderilmiştir. Bunlardan ilki 13 Ağustos 1860'ta Karadağ Prensi (Başknez) olan Nikola'y1 tebrik etmekle görevlendirilerek Çetine'ye gönderilmesi olmuştur. ${ }^{24}$ Aynı günlerde Karadağ hududundaki emlak ve arazinin durumunun tespiti için oluşturulmasına karar verilen muhtelit komisyona Başknez Nikola tarafından üye tespit edilmesi talebini içeren bir yazıyı götürmekle de görevlendirilmiştir. ${ }^{25} 1860$ yılının Ekim ayı başında Çetine'ye gönderilen Vasa Efendi'nin yapmış olduğu görüşmeler neticesinde sınır problemini halletmeye istekli olan Vladika Nikola'nın katkılarıyla sınır anlaşmazlıklarını gidermek üzere yeni bir komisyon kurulmuştur. İki tarafin da beşer üye verdiği Komisyonda Osmanlı tarafını Ordu-yı Hümâyûn Altıncı Şişhaneci Taburu Binbaşısı Ali Efendi, Ülgün Müdürü Raif Efendi, Vasa Efendi, yerli halktan Hafız Bey ve Mahmud Ağa temsil etmiştir. Komisyon, 21 Ekim 1860'da Vir Köyü’nde çalışmalarına

${ }^{18}$ BOA, Sadâret Âmedî Kalemi Defterleri (A.AMD), 85/46, H. 1274 (1257-1258).

${ }^{19}$ BOA, Irade Meclis-i Vala (I.MVL), 389/16953, H. 01.07.1274 (15 Subat 1858).

${ }^{20}$ BOA, Sadaret Mektubi Kalemi Umum Vilayat Evrakı (A.MKT.UM), 334/67, H. 15.04.1275 (22 Kasim 1858)

${ }^{21}$ BOA, A.MKT.UM, 348/50, H. 15.09.1275 (18 Nisan 1859).

22 BOA, Hariciye Nezareti Mektubi Kalemi Evrakı (HR.MKT), 294/69, H. 28.11 .1275 (29 Haziran 1859).

${ }^{23}$ BOA, HR.MKT, 296/3, H. 08.12.1275 (9 Temmuz 1859).

${ }^{24}$ BOA, DH.SAID.d, 1/236, H. 29.12.1241 (4 Ağustos 1826).

${ }^{25}$ BOA, HR.MKT, 355/94, H. 29.04.1277 (14 Kasim 1860). 


\section{KATOLIKK BİR OSMANLI BÜROKRATI VE ARNAVUT MILLLIYETÇİSI PAŞKO VASA \\ PAŞA (1852-1892)}

başlamıştır. Karadağlıların daha ilk toplantıda tartışmalı arazileri sınırlarına dâhil etmeye çalışması ve Osmanlı komiserlerinin buna karşı çıkması iki taraf komiserleri arasında yoğun bir tartışmaya sebep olmuştur. Bu yüzden çalışmalar daha başlangıçta sekteye uğramıştır. Komisyonun başarısız olması üzerine, Karadağlılar Nikşiç ve İşbuzi gibi tartışmalı sınır bölgelerini ele geçirmek üzere saldırılarını arttırmışlardır. Karadağlıların on bin kişilik bir kuvvetle 21 Şubat 1861'de İşbuzi'ye giden zahire konvoyuna saldırmaları yeni çatışmaların fitilini ateşlenmiştir. Önceki saldırılarda mülkî ve askerî yetkililerden dikkatli olunması veya savunmada kalmaları istenirken, İşbuzi saldırısından sonra yapılacak saldırılara hemen karşılık verilmesi istenilmiştir. Ağustos ayına gelindiğinde ise Karadağ'a karşı askerî bir harekât konuşulmaya başlanmıştır. ${ }^{26}$

Vasa Efendi, 1861 yılında Hersekli isyanc1ları destekleyip asker toplayarak kuvvetlerini seferi duruma getirmeye çalışan Karadağ'a karş1 Serdar Ömer Paşa kumandasında yapılan sefer esnasında 1500 kuruş maaş ile Meclis-i Askeri Azalığına getirilmiştir. ${ }^{27}$ Söz konusu askerî harekât 31 Ağustos 1861 'de İşkodra'da Karadağ ile imzalanan barış antlaşmasıyla sona ermiştir. $^{28}$

Her ne kadar Karadağ ile bir barış antlaşması imzalanarak savaş hali sona erdirilmiş olsa da bölgede Karadağlılar ile Arnavutlar arasındaki çatışmalar eksik olmamıştır. Karadağlıların Vranine köyünü basarak yakmaları ve buradaki askerî kulelere saldırmalarıyla İşkodra'da yeni hadiseler yaşanmaya başlamıştır. Karadağlıların baskını esnasında en az seksen askerin bulunması gereken Vranine kulesinde yirmi askerin bulunması, İşkodra'dan bölgeye asker sevkinin gecikmesi halkın İşkodra Mutasarrıfı ve Fırka-i Askeriye Kumandanı Çerkes Abdi Paşa'ya kızgınlıklarına sebep olmuş ve buna bağlı olarak olaylar başlamıştır. Alınan idari ve adli tedbirlerin yanı sıra Abdi Paşa'nın azledilerek yerine askerî ve mülkî iki yeni idarecinin atanmasıyla olayların önü alınmaya çalışııııştır. Bu esnada Ahmet Cevdet Paşa, sürecin sağlıklı bir şekilde yürümesini sağlamak ve tahkikat yapmak için idârî, askerî ve mülkî alanlarda fevkalâde komiser

\footnotetext{
${ }^{26}$ Zafer Gölen, "Karadağ Devleti'nin Doğuşu: Osmanl1-Karadağ Sınır Tespiti (1858-60)", Belleten, C. LXXVIII, S. 282, Ağustos 2014, s. 689-691.

${ }^{27}$ BOA, DH.SAID.d, 1/236, H. 29.12.1241 (4 Ağustos 1826).

${ }^{28}$ Midhat Sertoğlu, Mufassal Osmanlı Tarihi, C. VI, 1. Bask1, Türk Tarih Kurumu Yay., Ankara 2011, s. 3119.
} 


\section{SAID OLGUN}

sıfatı ile Eylül 1861'de İşkodra'da görevlendirilmiştir. ${ }^{29}$ Ahmet Cevdet Paşa'nın fevkalade memuriyetle İşkodra'ya gönderilmesi üzerine Vasa Efendi, onun maiyetinde tercüman ve Fransızca kâtibi olarak görevlendirilmiştir. ${ }^{30}$

Vasa Efendi'nin İşkodra hükümet tercümanlığı ve idare meclisi üyeliğindeki gayret ve başarısı yalnızca Osmanlı hükümeti tarafindan değil Rusya tarafından da takdir edilmiştir. 1862 yılında Rusya tarafından Saint Stanislaus nişanının üçüncü rütbesiyle ödüllendirilmiştir. Bu ödüllendirmenin hemen ardından çalışmalarını ve sadakatini takdir etmek amacıyla Osmanlı Devleti tarafindan 20 Ağustos 1862'de Beşinci Rütbeden Mecidî Nişanı verilmiştir. ${ }^{31}$

Vasa Efendi, 1862 y1lının sonlarında Hersek Kumandanı Abdi Paşa'nın maiyetinde tercümanlık yapmak üzere İşkodra Vilayeti Hükümet Tercümanlığı görevinden istifa etmiştir. ${ }^{32}$ İşkodra' daki görevi esnasında 1500 kuruş maaş alan Vasa'ya yeni görevi dolayisıyla ilk etapta 3000 kuruş maaş verilmesi düşünülmüssse de bunun uygun olmayacağına karar verilerek maaşı 2000 kuruş olarak belirlenmiştir. ${ }^{33}$ Abdi Paşa, 19 Şubat 1863'te "erbâb-l istikamet ve sadakat ve ehliyetten" olduğunu belirttiği Vasa Efendi'ye rütbei salise tevcih edilerek hali hazırda sahip olduğu Ǘçüncü Rütbe Mecidiye Nişanının Dördüncüye tebdil edilmesini istemiştir. ${ }^{34}$ Bunun yanı sıra Abdi Paşa, Yanya ve Yenişehir havalisindeki yeni görevi dolayısıyla ihtiyaç duyduğu tercümanın daha önceki çalışmalarından memnun olduğu Vasa Efendi olmasını talep etmekten de geri durmamıştır. ${ }^{35}$ Ancak Abdi Paşa'nın bu talebi uzun bir süre karşı1lı görmemiş ve Vasa Efendi, Bosna'daki görevine devam etmiştir. Bununla birlikte 13 Temmuz 1863 tarihli bir yazıyla Sadaret makamı, Bosna'da bulunan Vasa Efendi'ye rütbe ve nişan talebinin o gün için uygun olmadığını ancak ileride gereğinin yapılacağını bildirme kararı almıştır. ${ }^{36}$ Eylül ayına gelindiğinde bu kez işin içerisine Ahmet Cevdet Paşa girmiştir. Vasa Efendi'nin talebi üzerine konuyu takip etmeye başlayan

${ }^{29}$ Osmanlı Arşiv Belgelerinde Arnavutluk, Yay. Haz. H. Yıldırım Ağanoğlu, vd., Başbakanlık Devlet Arşivleri Genel Müdürlüğü Yay., İstanbul 2008, s. 262-263.

${ }^{30}$ BOA, DH.SAID.d, 1/236, H. 29.12.1241 (4 Ağustos 1826).

${ }^{31}$ BOA, Irade Hariciye (I.HR), 195/11070, H. 23.03.1279 (18 Eylül 1862).

${ }^{32}$ BOA, Irade Dâhiliye (İ.DH), 501/34094, H. 20.07.1279 (11 Ocak 1863).

${ }_{33}^{33}$ BOA, Sadaret Mektubi Mühimme Kalemi Evrakı (A.MKT.MHM), 253/43, H. 29.07.1279 (20

Ocak 1863).

${ }^{34}$ BOA, I.DH, 516/35131, H. 05.05.1280 (18 Ekim 1863).

${ }^{35}$ BOA, İ.DH, 516/35131, H. 05.05.1280 (18 Ekim 1863).

${ }^{36}$ BOA, A.MKT.MHM, 269/49, H. 26.01.1280 (13 Temmuz 1863). 


\title{
KATOLIKK BİR OSMANLI BÜROKRATI VE ARNAVUT MILLLIYETÇİSI PAŞKO VASA \\ PAŞA (1852-1892)
}

Cevdet Paşa'nın 27 Eylül 1863'te Sadaret'ten konunun akıbetini sorması üzerine yeni bir gelişme yaşanmış ve 19 Ekim 1863 tarihli bir iradeyle Vasa Efendi'ye Rütbe-i Salise verilmiştir. ${ }^{37}$

Yukarıda da bahsedildiği üzere 1861 yılında Ahmet Cevdet Paşa'nın İşkodra'da bulunduğu dönemde Meclis-i İdare üyeliğine devam eden Vasa, Cevdet Paşa'nın maiyetinde tercümanlık ve Fransızca Kâtiplik görevlerinde bulunmuştu. ${ }^{38} \mathrm{Bu}$ dönemde Ahmet Cevdet Paşa ile aralarında bir samimiyet oluşmuş ve yolları daha sonra birkaç kez daha kesişmiştir. Ahmet Cevdet Paşa, Ziya Bey'in görevinden alınması üzerine Haziran 1863'te BosnaHersek bölgesinin teftişiyle görevlendirilmiştir. Mostar'a ulaşan Ahmet Cevdet Paşa, burada daha önce birlikte çalıştı̆̆ 1 Vasa Efendi'yi görmüş ve bundan çok büyük memnuniyet duymuştur. Cevdet Paşa, bu durumu şu şekilde ifade etmiştir:

\begin{abstract}
"Bosna tarafinda bulunan teftiş kurulu müsteşarı Belgradlı Raşid Paşa, teftiş heyetiyle birlikte Mostar'a geldi. Heyetin içinde Vaso Efendi (halen Cebel-i Lübnan Mutasarrifi olan Vaso Paşa) de vardı. Vaso Efendi daha önce ben Işsodra'da iken o da Meclis-i İdare üyesi olmakla birlikte tercümanlı görevini de üstlenmistir. Bu sırada aramızda bir samimiyet meydana gelmiş olduğundan, onu burada bulduğumdan dolayı memnun oldum ve Bosna-Hersek'te kaldığımız müddet içinde büyük hizmetlerini gördüm ve sadakatini tecrübe ettim; sonra da devlete önemli hizmetlerde bulundu ve nihayet mükâfatını da Padişahımızdan görmüştür." 39
\end{abstract}

Ahmet Cevdet Paşa'nın Teftiş Heyetinde en sık bir araya geldiği isimlerden biri heyet tercümanı olması ve çok sık bir şekilde bölgedeki hem yerli halkla hem de yabancı ülke temsilcileriyle görüşülmesi nedeniyle Vasa Efendi olmuştur. ${ }^{40}$ Ahmet Cevdet Paşa, Vasa Efendi ile zorunlu görüşmeleri dışında da zaman zaman görüşüp onunla çeşitli siyasî ve tasavvufî konularda sohbet etmekten oldukça memnun olmuştur. ${ }^{41}$ Vasa Efendi, 1865 yılında

37 BOA, I.DH, 516/35131, H. 05.05.1280 (18 Ekim 1863); BOA, Tasra Evrakı Bosna Müfettişliği (TŞRBNM), 7/3, H. 13.04.1280 (27 Eylül 1863); BOA, A.MKT.MHM, 281/95, H. 15.05.1280 (28 Ekim 1863)

${ }^{38}$ BOA, DH.SAID.d, 1/236, H. 29.12.1241 (4 Ağustos 1826).

${ }^{39}$ Ahmed Cevdet Paşa, Sultan Abdülhamid'e Arzlar (Ma 'rûzât), Yay. Haz. Yusuf Halaçoğlu, 1. Baskı, Babıali Kültür Yayıncılı̆̆ı, İstanbul 2010, s. 78. Ahmed Cevdet Paşa, Tezâkir, No. 13-20, Yay. Haz. Cavid Baysun, 3. Bask1, Türk Tarih Kurumu Yay., Ankara 1991, s. 268.

${ }^{40}$ Ahmed Cevdet Paşa, Ma rûzât, s. 90.

${ }^{41}$ Ahmed Cevdet Paşa, Ma rûzât, s. 123. 


\section{SAİD OLGUN}

Fransızca olarak kaleme aldığı La Bosnie et L'Herzégovine pendant La Mission de Djevdet Efendi (Cevdet Efendi'nin Görevi Esnasında Bosna Hersek) isimli kitabında Cevdet Paşa'nın müfettişliği dönemindeki Bosna ve Hersek'in durumu ile Cevdet Paşa'nın uygulamaları hakkında bilgiler vermiştir. ${ }^{42}$

Bosna-Hersek'teki görevinden sonra İstanbul'a giden Vasa Efendi, mülazemet suretiyle Tahrirât-1 Ecnebiyye Odası'na devam etmiştir. 1865 y1lında 2000 kuruş maaşla ikinci defa İşkodra Vilayeti Hükümet Tercümanlığına atanmıştır. ${ }^{43}$

Ahmet Cevdet Paşa, 1863 yılı baharından 1864 yılı Ekim ayına değin yaklaşık yirmi ay boyunca birlikte çalıştı̆̆ $1,{ }^{44}$ zekâ ve kabiliyetiyle dikkatini çeken Vasa Efendi'yi Adana ve Halep eyaletlerinin birleştirilmesiyle oluşturulan Halep Vilayetine vali olarak atandığında beraberinde Politika Müdür Muavini olarak götürmüştür. ${ }^{45} 4$ Mart 1866 'da İstanbul'dan yola çıkan Ahmet Cevdet Paşa, Vasa Efendi ve beraberlerindeki memurlar, Mayıs ayında Halep'e ulaşarak vilayetteki idarî ve askerî teşkilatlanmayı başlatmışlardır. ${ }^{46} 5000$ kuruş maaşla bu göreve başlayan Vasa Efendi, 1867

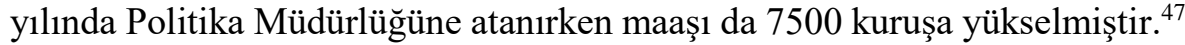

27 Ocak 1869'da Divân-1 Ahkâm-1 Adliye Mümeyyizliğine tayin edilen Vasa Efendi'ye ${ }^{48}$ Rütbe-i Saniye Sınıf-1 Mütemayiz tevcih edilmiş ve 4000 kuruş maaş verilmiştir. ${ }^{49} 15$ Eylül 1869'da Rütbe-i Evvel Sınıf-1 Sani tevcihiyle 7500 kuruş maaşla Divân-1 Ahkâm-1 Adliye Mahkeme-i Nizâmiyesi azalığına tayin edilmiştir. ${ }^{50}$

\footnotetext{
${ }^{42}$ Pasco Wassa Efendi, La Bosnie et L'Herzégovine pendant La Mission de Djevdet Efendi, Imprimerie du "Courrier d'Orient", Constantinople 1865.

${ }^{43}$ BOA, DH.SAID.d, 1/236, H. 29.12.1241 (4 Ağustos 1826).

${ }^{44}$ Elsie, Historical Dictionary of Albania, s. 465.

${ }^{45}$ Derviş Hima, Musavver Arnavut, Matbaa-i Şems, İstanbul 1327 (1910), s. 108-109.

${ }^{46}$ Ahmed Cevdet Paşa, Ma 'rûzât, s. 196-197.

${ }^{47}$ BOA, DH.SAID.d, 1/236, H. 29.12.1241 (4 Ağustos 1826).

48 BOA, Şura-yı Devlet Evrakı (ŞD), 2212/37, H. 08.11.1285 (20 Şubat 1869); BOA, A.MKT.MHM, 437/83, H. 23.11.1285 (7 Mart 1869).

${ }^{49}$ BOA, DH.SAID.d, 1/236, H. 29.12.1241 (4 Ağustos 1826).

${ }^{50}$ BOA, I.DH, 598/41670, H. 07.06.1286 (14 Eylül 1869); BOA, DH.SAID.d, 1/236, H. 29.12.1241 (4 Ağustos 1826).
} 


\section{KATOLIKK BİR OSMANLI BÜROKRATI VE ARNAVUT MILLIYYTÇíSI PAŞKO VASA PAŞA (1852-1892)}

1876 y1lında 4000 kuruş maașla Divan-1 İstinaf Cinayet Dairesi Azalığına atanan Vasa Efendi, ${ }^{51} 15$ Şubat 1876 'da 10000 kuruş maaşla Hersek Islahat Komisyonu Riyaseti'ne tayin edilmiştir. Bosna ve Hersek için ayrı ayrı oluşturulan her iki komisyonun amac1, ferman-1 adaleti (adaletname) ve buna bağlı olarak devlete itaate meyilli olanlara uygulanacak olan affi hayata geçirmekti. Bosna İcraat Komisyonu Başkanlığına Meclis-i Ali-i İcraat Azası Haydar Efendi atanırken Hersek Komisyonu Başkanlığına Vasa Efendi atanmıştır. Komisyonlara bulundukları yerlerdeki İdare Meclisleri marifetiyle ikisi Müslim ikisi Gayrimüslim olmak üzere dört aza seçilmesine ve bunlara 1500 kuruş maaş verilmesine karar verilmiştir. ${ }^{52}$

2 Mayıs 1876'da Rusya'nın kışkırtması ile Avretalan köyünde Bulgarlarca büyük bir isyan başlatılmıştır. İsyan kısa süre içerisinde Filibe sancağından Sofya, İslimye ve Tırnova'ya yayılmıştır. Rus yanlısı Mahmud Nedim Paşa hükümetinin umursamaz tavrı neticesinde büyüyen isyan, nihayet durumun ciddiyetini fark eden hükümetin gönderdiği kuvvetler ve halkın yardımıyla bastırılabilmiştir. Filibe ve civarında yaşanan bu olaylar, başta İngiltere olmak üzere Avrupa kamuoyu tarafindan Osmanlı Devleti aleyhine bir propaganda aracına dönüştürülmüştür. V. Murad döneminde bölge halkını teskin etmek için bölgeye gönderilen görevliler aracılığıyla nasihatlerde bulunulmuştur. İngiltere'nin baskılarının II. Abdülhamid döneminde devam etmesi üzerine meydana gelen olayları incelemek üzere 18 Eylül 1876 'da Filibe Olağanüstü Komisyonu kurulmuştur. ${ }^{53}$ Başkanlığına Mabeyn eski Başkâtibi Sadullah Bey'in getirildiği komisyonda Vasa Efendi de yer almıştır. ${ }^{54}$ Komisyonda Vasa Efendi ile birlikte görev yapan bir başka Arnavut Avlonyalı İsmail Kemal Bey olmuştur. ${ }^{55}$

1876 yılında Manastır Vilayeti Vali Muavinliğine atanan Vasa Efendi, kısa süre içerisinde bu görevinden ayrılarak 1877 yılında Kosova Vilayeti Müsteşarlığına atanmıştır. ${ }^{56} 12500$ kuruş maaşla yeni görevine

${ }^{51}$ BOA, DH.SAIDD.d, 1/236, H. 29.12.1241 (4 Ağustos 1826).

${ }_{52}$ BOA, Irade Meclis-i Mahsus (İ.MMS), 54/2388, H. 18.01.1293 (14 Şubat 1876); BOA, Yıldız Esas Evraki (Y.EE), 77/10, H. 19.01.1293 (15 Şubat 1876).

${ }^{53}$ Ali Akyıldız, Sürgün Sefir Sadullah Paşa, Türkiye İş Bankası Kültür Yay., 1. Baskı, İstanbul 2011, s. 57-59.

${ }^{54}$ Aky1ldiz, a.g.e., s. 417; BOA, DH.SAID.d, 1/236, H. 29.12.1241 (4 Ağustos 1826); BOA, Y.EE, 84/69, H. 29.08.1293 (19 Eylül 1876).

55 Ísmail Kemal Bey'in Hatıratı, Ed. Sommerville Story, çev. Adnan İslamoğulları, Rubin Hoxha, Tarih Vakfi Yurt Yayınları, İstanbul 2007, s. 137.

${ }^{56}$ BOA, DH.SAID.d, 1/236, H. 29.12.1241 (4 Ağustos 1826); “Turkey’s Danger”, Pall Mall Gazette, 10 February 1877, s. 11. 


\section{SAID OLGUN}

başlayan Vasa Efendi'nin sahip olduğu Rütbe-i Evvel Sınıf-1 Sani'si atandığg yeni görevine uygun olması düşüncesiyle 23 Şubat 1877'de Rütbe-i Evvel Sinıf-1 Evvel'e yükseltilmiştir. ${ }^{57}$ Kısa bir müddet sonra 30 Ağustos 1877 'de hizmeti ve sadakati göz önünde bulundurularak sahip olduğu Beşinci Rütbe Mecidiye Nişanı Üçüncü Rütbeye yükseltilmiştir. ${ }^{58}$

1878 yılı içerisinde Rodop Balkanı Komiserliği'ne atanan Vasa Efendi, ${ }^{59}$ Sami Paşa ile birlikte bölgedeki isyanı bastırma hususunda diğer görevlilere yardımcı olmakla vazifelendirilmiştir. Mayıs ayında Rodop'a ulaşan Sami Paşa ve Vasa Efendi, isyancılarla görüşerek ayaklanmanın sona erdirilmesine gayret göstermişlerdir. ${ }^{60}$ Aynı yıl içerisinde 6000 kuruş maaşla Şura-yı Devlet azalığına atanmış daha sonra ek bir memuriyet olarak 1879 yılının Mart ayından itibaren Matbuat İdaresi Vekâletinde görevlendirilmiştir. ${ }^{61}$

Vasa Efendi, 1879 yılının Ağustos ayında 10000 kuruş maaşla Edirne Vilayeti Müsteşarlığına atanmıştır. ${ }^{62} \mathrm{Bu}$ esnada Berlin Antlaşması gereğince Rumeli vilayetlerinin idaresi için hazırlanan nizamnameyi tetkik etmek üzere Avrupa Komisyonu adında bir heyet oluşturulmuştur. Heyetin içerisinde Osmanlı Devleti'ni temsilen Asım Paşa ve Sahak Abro Efendi komiser olarak görevlendirilmişlerdir. Komisyonun yerine getireceği vazifenin önemini göz önünde bulunduran hükümet, Vasa Efendi'nin üçüncü komiser sıfatıla komisyonda görevlendirilmesine karar vermiştir. ${ }^{63}$

1877-1878 Osmanlı-Rus Harbi sonrası ortaya çıkan durum karşısında Arnavutlar tarafından kurulan Prizren Birliği, Berlin Antlaşmasının sınırlarla ilgili hükümlerinin uygulanmasındaki en büyük engellerden biri olmuştur. Karadağlılar ile Arnavutlar arasında çok ciddi çatışmalar yaşanmıştır. Hükümet bu çerçevede yaşanan olayların önünü almak ve Arnavutları teskin etmek için birtakım yollara başvurmuştur. Berlin Kongresi'nde Osmanlı Devleti'ni temsil eden Müşir Mehmed Ali Paşa, antlaşmanın hükümlerinin

${ }^{57}$ BOA, I. $D H, 742 / 60654$, H. 08.02.1294 (22 Şubat 1877).

${ }^{58}$ BOA, I.DH, 753/61491, H. 19.08.1294 (29 Ağustos 1877).

${ }^{59}$ BOA, DH.SAID.d, 1/236, H. 29.12.1241 (4 Ağustos 1826); BOA, ŞD, 276/47, H. 18.10.1296 (5 Ekim 1879).

60 "The Military Situation", Shipping and Mercantile Gazette, 10 May 1878, s. 2.

${ }^{61}$ BOA, DH.SAID.d, 1/236, H. 29.12.1241 (4 Ağustos 1826); BOA, ŞD, 276/47, H. 18.10.1296 (5 Ekim 1879).

${ }^{62}$ BOA, Dahiliye Nezareti Şifre Evrakı (DH.ŞFR), 112/46, H. 09.06.1295 (31 Mayıs 1879).

${ }^{63}$ BOA, Yildiz Sadaret Resmi Maruzat Evrakı (Y.A.RES), 6/11, H. 21.07.1297 (29 Haziran 1880). 


\section{KATOLIKK BİR OSMANLI BÜROKRATI VE ARNAVUT MILLLIYETÇİSI PAŞKO VASA \\ PAŞA (1852-1892)}

bölgede uygulanması için görevlendirilmiştir. Arnavutların İstanbul'a dönmesi yönünde yoğun bir şekilde baskı yaptıkları Mehmet Ali Paşa, Yakova'da Abdullah Paşa'nın konağında misafir bulunduğu esnada etrafi kuşatılmış ve çıkan çatışmada 6 Eylül 1878'de önce Abdullah Paşa daha sonra da Mehmet Ali Paşa öldürülmüştür. ${ }^{64}$ Abdullah Paşa ve Mehmed Ali Paşa'nın öldürülmesini Vasa şu şekilde değerlendirmiştir:

“O (Abdullah Paşa), Mehmed Ali Paşa’nın görüşlerini kabul ettiği, millî onur ve haysiyetin aleyhinde çalıştı̆̆ şüphesiyle vatandaşları tarafindan öldürülen ilk kişi oldu. Öyle tahmin ediyorum ki herhangi bir şef millî duygulart tahrip etmeye ve değiştirmeye teşebbüs edecek olursa akıbeti Abdullah Paşa ve Mehmed Ali Paşa ile birlikte öldürülenlerle aynı olacaktır." 65

Söz konusu dönemde merkezî hükümet tarafindan Vasa Efendi’nin de bölgede görevlendirilerek, Arnavutların teskin edilmesi ve Prizren Birliği'nin dağıtılması tasarlanmıştır. $\mathrm{Bu}$ çerçevede 1880 yılında Arnavutluk'a gönderilmek istenilen Vasa Efendi, alttan alta desteklediği Arnavutlarla karşı karşıya gelmemek adına girişimlerinin başarıya ulaşamayacağını da göz önünde bulundurarak görevi reddetmiş̧ir. ${ }^{66}$

1882 y1lında Vasa Efendi'nin Cezayir-i Bahr-i Sefid Vilayetine bağlı Rodos Sancağına Mutasarrıf olarak atanması söz konusu olmuştur. 2 Ocak 1882'de Cezayir-i Bahri Sefid Valiliğince vilayete muktedir ve muttaki Müslüman mutasarrıflar atanmasının daha uygun olacağı ancak Müslüman mutasarrıflardan beklenen iyi idareciliğin ve sadakatin Vasa Efendi tarafından da gösterilmesi nedeniyle atanmasının padişahın takdirinde olduğu ifade edilmiştir. ${ }^{67}$ Hakkındaki olumlu kanaate rağmen Vasa Efendi'nin Rodos mutasarrıflığına ataması gerçekleşmemişse de 6 Mayıs 1882'de sahip olduğu Rütbe-i Evvel Sınıf-1 Evvel'in Balâ'ya yükseltilmesine karar verilmiştir. ${ }^{68}$

\footnotetext{
${ }^{64}$ Süleyman Külçe, Osmanlı Tarihinde Arnavutluk, Yeni Asır Matbaası, İzmir 1944, s. $257-$ 258.

${ }^{65}$ Stavro Skendi, The Albanian National Awakening 1878-1912, Princeton University Press, Princeton (New Jersey) 1967, s. 58.

66 "Turkey and the Powers", Greenock Advertiser, 7 July 1880, s. 2; "Turkey and the Power", The Batch Chronicle, 8 July 1880, s. 6; "Turkey and the Powers", The Ayr Advertiser or West Country and Galloway Journal, 8 July 1880, s. 7; "Turkey and the Powers", The Manchester Courier and Lancashire General Advertiser, 8 July 1880, s. 8; Skendi, a.g.e., s. 57.

${ }^{67}$ BOA, Yıldız Sadaret Hususi Maruzat Evrakı (Y.A.HUS), 169/41, H. 24.02.1299 (15 Ocak 1882).

${ }^{68}$ BOA, I.DH, 853/68443, H. 17.06.1299 (6 May1s 1882).
} 


\section{SAİD OLGUN}

\section{Cebel-i Lübnan Mutasarrıflığına Atanması}

1861 yılında hazırlanan Cebel-i Lübnan Nizamnamesinin birinci maddesine göre Cebel-i Lübnan'ın Osmanlı Devleti tarafindan tayin edilen Hıristiyan bir mutasarrıf tarafından yönetilmesine karar verilmiştir. Buna bağlı olarak 1861-1868 yılları arasında Davud Paşa (1816-1877), ${ }^{69}$ 18681873 yılları arasında Nasri Franko Paşa (1814-1873), 1873-1883 yıllarında ise Rüstem Paşa ${ }^{70}$ Cebel-i Lübnan Mutasarrıfı olarak görev yapmıştır. ${ }^{71}$ On y1l süreliğine bu göreve atanan Rüstem Paşa'nın görev süresi 23 Nisan 1883 'te dolacağ 1 için hem Osmanlı hükümeti hem de Büyük Devletler, yeni bir mutasarrıf arayışı içerisine girmişlerdir. Bölgedeki genel politikasına uymayan Rüstem Paşa'yı hamiliğini üstlendiği Marunîler tarafından sevilmediği için istemediğini belirten Fransa, mutasarrıfın görev süresinin uzatılması ihtimalini, mutasarrıfın belirlenmesinde uygulanagelen oy birliği teamülü nedeniyle ortadan kaldırıyordu. ${ }^{72}$ Marunîleri arkasına alarak bölgedeki etkinliğini daha da artırma çabası içerisindeki Fransa, Rüstem Paşa hakkındaki olumlu genel kanaate rağmen onun yerine kendi çıkarlarına hizmet edecek birisinin atanması için yoğun bir çaba sarf etmiştir. Buna bağlı olarak Fransa, Rüstem Paşa'yı itibarsızlaştırarak yıpratmak ve yeniden atanmasını engellemek için Marunîler tarafından çeşitli şikâyet dilekçelerinin kaleme alınmasını sağlamıştır. ${ }^{73}$

Babıâli’nin mutasarrıflık için üzerinde durduğu ve Büyük Devletlere önerdiği ilk isim, İşkodralı Katolik Arnavutlardan Prenk Bib Doda olmuştur. ${ }^{74}$ Mirdit kabilesi liderlerinden daha 24 yaşındaki genç ve tecrübesiz bu aday, ${ }^{75}$ Fransa tarafindan uygun bulunmasına rağmen, İngiltere'nin

\footnotetext{
${ }^{69}$ Davud Paşa ve Cebel-i Lübnan'daki faaliyetleri için bk. Saro Dadyan, “1861 Cebel-i Lübnan Nizamnamesi ve Özerk Cebel-i Lübnan'ın İlk Mutasarrıfı Garabed Artin Davud Paşa”, Toplumsal Tarih, S. 239 (Kasim 2013), s. 22-26.

${ }^{70}$ Rüstem Paşa ve Cebel-i Lübnan'daki faaliyetleri hakkında bk. Can Ünsal, Rüstem Paşa 'nın Mutasarrıflığı Döneminde Cebel-i Lübnan (1873-1883), Eskişehir Osmangazi Üniversitesi Yayımlanmamış Yüksek Lisans Tezi, Danışman: Yrd. Doç. Dr. Musa Kılıç, Eskişehir 2017.

${ }^{71}$ Maurus Reinkowski, Düzenin Şeyleri, Tanzimat'ın Kelimeleri, çev. Çiğdem Canan Dikmen, Yapı Kredi Yayınları, İstanbul 2017, s. 70-72. II. Abdülhamid döneminde Cebel-i Lübnan'da mutasarrıf olarak görev yapan Hıristiyan mutasarrıflar hakkında bilgi için bk. Kırmızı, a.g.t., s. 66-75.

${ }^{72}$ St. James Gazette, 13 March 1883, s. 5.

${ }^{73}$ Ünsal, a.g.t., s. 70-75.

74 "The Lebanon", Dublin Daily Express, 27 April 1883, s. 2.

75 "Occasional Notes", Pall Mall Gazette, 7 May 1883, s. 3; The Morning Post, 7 January 1884, s. 4; Morning Post, 24 April 1883, s. 5.
} 


\section{KATOLIKK BİR OSMANLI BÜROKRATI VE ARNAVUT MILLLIYETÇİSI PAŞKO VASA PAŞA (1852-1892)}

muhalefeti ve Rusya'nın kabul etmemesi nedeniyle bu göreve atanamamıştır. $^{76}$

II. Abdülhamid'in görevine devam etmesini istediği Rüstem Paşa'nın yerine Fransızların mutasarrıf olarak görmek istedikleri en favori isim bir Marunî olan ve Viyana elçiliğinde görev yapan Nasri Franko Kusa olmuştur. Nasri Franko Kusa'nın yanı sıra Edirne Müsteşarlığı görevinde bulunan Katolik Arnavutlardan Vasa Efendi, Ermeni asıllı Posta ve Telgraf Müdürlüğü görevinde bulunan Yaver Paşa ve Polonya asıllı Sadık Paşa'nın oğlu Muzaffer Paşa bu görev için isimleri zikredilen kişiler olmuştur. ${ }^{77}$

Fransa'nın karşı durduğu Rüstem Paşa'nın görevini devam ettirmesinin mümkün olmadığının anlașılması üzerine yerine alternatif isimler teklif edilmiştir. ${ }^{78}$ Viyana Sefareti Başkâtibi Nasri Franko Kusa, Memurin-i Adliyeden Petro Efendi, Orman ve Maadin Müdür-i Umumisi Bedros Kuyumcuyan Efendi, Edirne Vali Müsteşarı Vasa Efendi ve Raguza Başşehbenderi Daniş Efendi isimleri Babıâli tarafından Cebel-i Lübnan Mutasarrıflığına namzet olarak tespit edilmiştir. Hariciye Nazırı Ahmed Arifi Paşa, Büyük Devletlerce daha kolay kabul edilebileceğini düşündüğü Daniş Efendi'nin en uygun isim olduğu kanaatindeydi. Ona göre Daniş Efendi, daha önce Fuat Paşa'nın maiyetinde Suriye'de bulunduğu için bölgeyi tanıması, ehliyeti, tecrübe edilmiş olan sadakati ve aranılan niteliklere sahip olması nedeniyle ön plana çıkıyordu. ${ }^{79}$

Dürzîler ve Marunîler arasında dengeyi gözetebilecek; Büyük Devletlerin tümü tarafından "persona grata" olarak kabul edilebilecek; sadakati sınanmış, tecrübeli, Hiristiyan bir Osmanlı devlet adamı bulmak Babıâli'nin göreviydi. ${ }^{80}$ Nihayet II. Abdülhamid'in tercihi Vasa Efendi yönünde olmuş ve 5 Mayıs 1883'te Sadaretten Düvel-i Muazzamanın sefirlerinin toplanarak sürecin tamamlanmasını istemiştir. ${ }^{81}$ Padişahın bu

76 BOA, Yıldız Perakende Evrakı Başkitabet Dairesi Maruzatı (Y.PRK.BŞK), 7/55, H. 13.06.1300 (21 Nisan 1883).

77 St. James Gazette, 13 March 1883, s. 5.

78 Ünsal, a.g.t., s. $70-75$.

${ }^{79}$ BOA, Yıldız Sadaret Resmi Maruzat Evrakı (Y.A.RES), 20/5, H. 11.06.1300 (19 Nisan 1883); BOA, Y.A.RES, 20/19, H. 16.06.1300 (24 Nisan 1883).

80 "French Intrigues in Lebanon", The Jersey Weekly Press and Independent, 17 March 1883, s. 2.

${ }^{81}$ BOA, Y.EE, 2/36, H. 27.06.1300 (5 Mayıs 1883); BOA, Irade Eyalet-i Mümtaze Cebel-i Lübnan (İ.MTZ.CL), 3/179, H. 27.06.1300 (5 May1s 1883); BOA, I.MTZ.CL, 3/180, H. 


\section{SAID OLGUN}

isteğine bağlı olarak Pazar gününe denk gelmesine rağmen 6 Mayıs 1883'te Hariciye Nezaretinde Düvel-i Sitte olarak nitelendirilen Avusturya, Almanya, İtalya, Fransa, İngiltere ve Rusya'nın İstanbul'da bulunan çeşitli düzeydeki temsilcileri bir toplantı yaparak konuyu ele almışlardır. ${ }^{82}$ Cebel-i Lübnan mutasarrıflığına yapılacak atama hakkında görüşmek üzere üçüncü defa bir araya gelen temsilcilere Vasa Efendi'nin mutasarrıflığa tayini hakkındaki irade tebliğ edilmiştir. ${ }^{83}$

Yapılan görüşme esnasında Avusturya Sefiri, hükümetinden Vasa Efendi hakkında herhangi bir talimat almadığını bununla birlikte Padişah tarafından seçilen ve diğer devletlerce rıza gösterilen bir zatı kabule yetkisi olduğunu belirterek olumlu kanaatini ifade etmiştir. Almanya Sefiri ise Vasa Efendi'nin dirayet ve marifetinden bahsederek Avusturya Sefiri ile ayn fikirde olduğunu beyan etmiştir. İtalya maslahatgüzarı da kendisinden önce söz alan Avusturya ve Almanya Sefirleriyle hem fikir olduğunu dile getirmiştir. Fransa sefiri ise diğer temsilciler gibi Vasa Efendi'nin seçilmesini kabul etmiştir. Ancak öteden beri görevden alınması için hakkında çeşitli entrikalar çevirdikleri Rüstem Paşa'nın görev süresi dolmuş olduğu için görevine usulsüz bir şekilde devam ettiğini ve biran evvel bu duruma bir son verilmesi gerekliliğini sözlerine ilave etmiştir. İngiltere maslahatgüzarı ise Vasa Efendi'nin dirayetinden bahsettikten sonra konu hakkında Londra'dan talimat isteyeceğini ve cevabın olumlu olacağını ümit ettiğini beyan etmiştir. Rusya sefiri de Petersburg'dan talimat isteyeceğini ve gelecek talimatın olumlu olacağından ümitli olduğunu ifade etmiştir. ${ }^{84}$ Yapılan görüşme neticesinde taraflar, Vasa Efendi'nin mutasarrıflığa atanması hususunda bir fikir birlikteliğine ulaşmışlardır. Buna bağlı olarak temsilciler, hükümetlerinden alacakları talimata (ad referendum) göre konuyu neticelendirmek ve bir protokol imzalamak üzere 8 Mayıs'ta bir araya gelme kararı almışlardır. ${ }^{85}$

27.06.1300 (5 May1s 1883); BOA, I.MTZ.CL, 3/181, H. 28.06.1300 (6 May1s 1883); BOA, I.MTZ.CL, 3/182, H. 03.07.1300 (10 Mayıs 1883).

82 BOA, Y.A.HUS, 173/62, H. 23.06.1300 (1 Mayis 1883).

${ }^{83}$ BOA, Y.A.HUS, 173/62, H. 23.06.1300 (1 May1s 1883).

${ }^{84}$ BOA, Y.A.HUS, 173/62, H. 23.06.1300 (4 May1s 1883)

85 "The Governorship of the Lebanon", London Evening Standard, 7 May 1883, s. 5; "The Governorship of the Lebanon", Pall Mall Gazette, May 7, 1883, s. 6; "The Governorship of the Lebanon", The Standard, 7 May 1883, s. 5; "The Governorship of the Lebanon", The Standard, 8 May 1883, s. 5; "Turkey", The Manchester Courier and Lancashire General Advertiser, 9 May 1883, s. 8; “The Lebanon Question”, The Dundee Advertiser, 7 May 1883, s. 6 . 


\section{KATOLIKK BİR OSMANLI BÜROKRATI VE ARNAVUT MILLIYYTÇíSI PAŞKO VASA PAŞA (1852-1892)}

8 Mayıs'ta Hariciye Nezaretinde bir araya gelen temsilciler, daha önce Rüstem Paşa'nın Cebel-i Lübnan Mutasarrıflığına atanması sırasında hazırlanan protokol metninin bir benzerini bu kez de Vasa Efendi için imzalamışlardır. ${ }^{86}$ Protokolde Padişah tarafından görev süresi dolan Rüstem Paşanın yerine Vasa Efendi'nin atandığı belirtildikten sonra 9 Haziran 1861 tarihli Cebel-i Lübnan Nizamnamesi ile 6 Ekim 1864, 27 Temmuz 1868 ve 22 Nisan 1873 tarihinde yapılan çeşitli düzenleme ve taraflar arasında imzalanan protokollere gönderme yapılarak bunlara uygun bir şekilde yeni mutasarrıfin on yıl süreyle bu göreve atandığı belirtilmiştir. ${ }^{87}$

Protokolün imzalanmasından sonra 10 Mayıs 1883 tarihli padişah iradesiyle "uhdesine rütbe-i samiyye-i vezaret tevcihiyle" paşalı unvanı verilen Vasa Paşa, resmen Cebel-i Lübnan Mutasarrıflığına atanmıştır. ${ }^{88}$ Bununla birlikte 23 Mayıs 1883'te çıkarılan bir irade ile sahip olduğu İkinci Rütbe Mecidi Nişanı Birinci Rütbeye yükseltilmiştir. ${ }^{89}$ Yaklaşık bir hafta sonra 31 Mayıs $1883^{\prime}$ te ise İkinci Rütbeden Osmanî Nişanı verilmiştir. ${ }^{90}$

Yapılan atamadan sonra 15 Mayıs'ta Yıldız'a giderek II. Abdülhamid ile görüşen Vasa Paşa, padişaha şükranlarını sunmuştur. Görüşme esnasında Abdülhamid'in görev yerine ne zaman gideceğini sorması üzerine Vasa Paşa,

86 “Turkey”, The Morning Post, 9 May 1883, s. 5; "The Lebanon”, The Standard, 9 May 1883, s. 5; "Latest Intelligence", The Lincoln, Rutland and Stamford Mercury, 11 May 1883, s. 4; "The Lebanon Governorship", The Evening Telegraph, 10 May 1883. "The Governorship of the Lebanon", Irish Times, 11 May 1883, s. 7; The Globe, 8 May 1883, s. 2; The Globe, 9 May 1883, s. 3; "Wassa Effendi", The Manchester Courier and Lancashire General Advertiser, 11 May 1883 , s. 6.

878 Mayıs 1883 tarihli protokolde Osmanlı Devleti adına Hariciye Nazırı Ahmed Arifi Paşa'nın Almanya adına Joseph von Radowitz'in, Avusturya Macaristan İmparatorluğu adına Baron Calice'in, Fransa adına Emmanuel Henri Victurnien de Noailles'in, İngiltere adına Hugh Wyndham'in, İtalya adına Luigi Avogadro di Collobiano Arborio'nun, Rusya adına Alexander Nelidov'un imzaları bulunuyordu. Gabriel Effendi Noradounghian, Recueil d'Actes Internationaux de L'Empire Ottoman, C. IV, Librairie Catillan, Paris, 1897, s. 314; "The Governorship of the Lebanon", London Evening Standard, 8 May 1883, s. 5; "Turkey - The Governorship of the Lebanon", Pall Mall Gazette, 10 May 1883, s. 8.

${ }^{88}$ BOA, Sadaret Eyalet-i Mümtaze Cebel-i Lübnan Evrakl (A.MTZ.CL), 1/18, H. 29.10 .1300 (2 Eylül 1883); BOA, I.MTZ.CL, 3/182, H. 03.07 .1300 (10 Mayıs 1883); BOA, DH.ŞFR, 116/72, R. 28.02.1299 (10 Mayıs 1883); "The Governorship of the Lebanon", The Standard, 10 May 1883, s. 5; Vasa Paşa'ya vezirlik rütbesi verilmesine dair Divân-1 Hümâyûn kaleminde yazılan menşur-i ali, 28 Mayıs 1883'te Paşa'nın Mekteb-i Harbiye civarındaki evinde düzenlenen bir törenle okunmuştur. BOA, I.DH, 886/70524, H. 16.07.1300 (23 Mayıs 1883). ${ }^{89}$ BOA, I.DH, 886/70524, H. 16.07 .1300 (23 May1s 1883); BOA, Hariciye Nezareti Siyasi (HR.SYS), 2943/26, M. 12 Mayıs 1883.

${ }^{90}$ BOA, DH.SAID.d, 1/236, 29.12.1241 (4 Ağustos 1826). 


\section{SAID OLGUN}

on beş güne kadar gitmek için gayret göstereceğini ifade ettikten sonra yol hazırlığı yapmak için yeterli imkânı olmadığını da ilave etmiştir. ${ }^{91} 17$ Mayıs'ta İstanbul'da görev yapan elçileri ziyaret eden Vasa Paşa, aynı gün İstanbul'dan ayrılmadan önce ikinci defa padişahla görüşmüştür. ${ }^{92} \mathrm{Bu}$ arada Vasa Paşa'nın müşkülatının giderilmesi için 20 Mayıs'ta Vasa Paşa'ya Maliye Hazinesinden 750 lira harcırah verilerek hızlı bir şekilde görevine gitmesinin sağlanmasına karar verilmiştir. ${ }^{93}$ Aldığ 1 ödenekle hızlı bir şekilde hazırlıklarını tamamlayarak İstanbul'dan yola çıkan Vasa Paşa, 6 Haziran 1883 sabahı Beyrut'a ulaşmıştır. ${ }^{94} 7$ Haziran'da Cebel-i Lübnan eşraf ve ayanı ile bölgede görev yapan memur ve askerlerin katılımıyla düzenlenen törende Vasa Paşa'nın Cebel-i Lübnan mutasarrıflığına atanmasına dair ferman okunmuş ve Rüstem Paşa, görevi halefine devretmiştir. Tören, Vasa Paşa'nın nasihat ve ihtarlarını içeren nutkundan sonra yapılan duayla sona ermiş ve böylece yeni mutasarrıf fiili olarak görevine başlamıştır. ${ }^{95}$

\section{Faaliyetleri}

\section{Vasa Pașa'nın Cebel-i Lübnan Mutasarrıflığındaki}

Vasa Paşa, göreve başladığı ilk günlerden itibaren bölgedeki etkinliğini artırma çabasındaki Fransa tarafından kontrol ve etki altına alınmaya çalışılmıştır. Cebel-i Lübnan'ın kendileri olmaksızın idare edilemeyeceğini düşünen Fransızların Vasa Paşa'yı kendi yanlarına çekecekleri yönündeki hayalleri, çok uzun sürmemiştir. Buna bağlı olarak Cebel-i Lübnan'ın kendileri olmaksızın yönetilemeyeceği şeklindeki düşünceleri, yerini yardımları olmaksızın yönetilemeyeceği düşüncesine terk etmiştir. ${ }^{96}$

Vasa Paşa, dönemin birçok devlet adamı gibi bir dönem Sadrazamlık da yapan Şam Valisi Ahmed Hamdi Paşa'ya büyük bir saygı gösterip onun görüş ve tavsiyelerini ciddiye alıyordu. Bu aşamada Ahmed Hamdi Paşa, Vasa Paşa'yı Dürzîler arasındaki rekabete; arazi sahibi Marunîler ile Ruhbanlar arasındaki çekişmeye; Marunî, Dürzî, Hıristiyan ve diğer

${ }^{91}$ BOA, Y.PRK.BŞK, 7/66, H. 08.07.1300 (15 May1s 1883); BOA, I.MTZ.CL, 3/184, H. 08.07.1300 (15 May1s 1883).

92 "Turkey", The Leeds Mercury, 17 May 1883, s. 3.

${ }^{93}$ BOA, I.MTZ.CL, 3/183, H. 13.07.1300 (20 May1s 1883).

${ }^{94}$ St. James Gazette, 6 June 1883 , s. 8.

${ }^{95}$ BOA, I.DH, 887/70613, H. 08.07.1300 (15 May1s 1883).

${ }^{96}$ John P. Spagnolo, France \& Ottoman Lebanon 1861-1914, Ithaca Press, London 1977, s. 175-176. 


\section{KATOLIKK BİR OSMANLI BÜROKRATI VE ARNAVUT MILLLIYETÇİSI PAŞKO VASA \\ PAŞA (1852-1892)}

mezhepler arasındaki çatışmaya ve büyük devletlerin değişen pozisyonlarına dikkat etmesi hususunda uyarmıştır. Ahmed Hamdi Paşa'nın Vasa Paşa'ya en önemli uyarısı Fransız konsolosunun ve Marunî Ruhbanların entrikalarına karşı uyanık olması olmuştur. Ahmed Hamdi Paşa'ya göre saltanata sadakatle bağlı olan Vasa Paşa, Cebel-i Lübnan'1 gerektiği gibi etkin bir şekilde yönetme yeteneğine sahipti. ${ }^{97}$

1884 yılında London Times gazetesinde Marunîlerin Fransiz himayesine girmek istedikleri yönünde birtakım haberlerin yayımlanması ve Babıâli'nin Vasa Paşa'ya "ciddi önlemlere ihtiyaç" duyulduğu yönünde telkinlerde bulunması onu Fransız konsolosuna ve Marunî Ruhbanlara karşı daha fazla teyakkuza sevk etmiştir. Vasa'nın telkinleriyle Maruni piskoposlar ve Patrik söz konusu çarpık haberi tekzip etmeye ikna edilmiş böylece bölgeye yabancıların müdahalesine bahane oluşturacak bir hadisenin de önüne geçilmiştir. ${ }^{98}$

Vasa Paşa, Fransa'nın bölgedeki emellerini engellemek için yerel çıkar gruplarının desteğini kazanmaya büyük bir önem vermiştir. Yerel yönetimdeki tecrübesi, müzakereci ve uzlaşmacı tavrı, onun Marunî kilisesiyle ilişkilerindeki tarzını göstermesi açısından önemlidir. Fransa ile kilise arasındaki bağı, Ruhbanlara yönetimi altındaki hiçbir gruba karşı inancı ve mezhebi dolayısıyla önyargıyla yaklaşmayacağı güvencesi vererek zayıflatacağına inanmıştır. Bu noktada Marunî din adamlarının hükümete düşmanlığını Rüstem Paşa'nın saygısız ve adaletsiz muamelesine bağlayan Vasa, Fransa'nın Marunî din adamları üzerindeki etkisini azaltmak yerine Ruhbanların Marunîler üzerindeki tesirini azaltmayı tercih etmiştir. Bu doğrultuda en fazla önem verdiği iki konudan ilki bölgedeki okul sayısının artırılmasıyken ikincisi de inşa edilecek yeni yollar vasıtasıyla ulaşımın kolaylaştırılması olmuştur. ${ }^{99}$ Tüm ekonomik problemlere ve muhalefete rağmen ilk etapta Beytüddin (Beiteddine) ile Beyrut arasındaki yolun daha sonra da Sidon (Sayda)'dan Beyrut ve Trablusşam'a uzanan yolun inşası için çalışmıştır. Özellikle Sidon'dan Beyrut ve Şam'a uzanan yolun birkaç millik kısmının dışında tümünün Cebel-i Lübnan'dan geçecek olmasına, inşaat için yapılacak harcamaların büyük bir kısmının Lübnan'da yapılacak ve böylece Lübnan ekonomisine büyük bir fayda sağlanacak olmasına rağmen yeniliklere kapalı taraflarca yolun Cebel-i Lübnan'a değil Osmanlı Devleti'ne

\footnotetext{
${ }^{97}$ Akarl1, a.g.e., s. 46.

${ }^{98}$ Akarl1, a.g.e., s. 46-47.

${ }^{99}$ Akarli, a.g.e., s. 47-48.
} 


\section{SAID OLGUN}

fayda sağlayacağı ifade edilerek karşı çıkılmıştır. ${ }^{100}$ Tüm bu karşı çıkış ve engellemelere rağmen Vasa Paşa'nın mutasarrıflığı esnasında toplamda 149 kilometrelik yol yapılmıştır. Kendisinden önce yirmi yıldan uzun süre görev yapan üç selefi döneminde, büyük oranda merkezî hükümet tarafından inşa edilen 108 kilometre yolla mukayese edildiğinde Vasa Paşa'nın büyük bir başarıya imza attığı söylenebilir. ${ }^{101}$

Vasa Paşa, bölgenin kalkınmasına yönelik proje ve planlarını hayata geçirebilmek için yeni birtakım uygulamalara başvurmak zorunda kalmıştır. Aldığı tasarruf tedbirleri sayesinde küçük de olsa ek bir finansman kaynağ 1 oluşturmayı başarmıştır. Bu çerçevede Cebel'deki askerlerin sayısı, \%20 oranında azaltılarak maaşlarında kesinti yapılmıştır. Tüm bunlara ek olarak görev ve sorumlulukları posta dağıtımını içerecek şekilde genişletilmiştir. Tasarruf tedbirleri adliye teşkilatının yapılanmasında gerçekleştirilen düzenlemelerle kendisi göstermiş ve bu çerçevede hâkim sayısı azaltılmıştır. İdare Meclisinin ve Fransa konsolosunun tüm muhalefetine rağmen ipek imalathanelerine vergi uygulanmaya başlanmıştır. ${ }^{102}$

Vasa Paşa, Cebel-i Lübnan Mutasarrıflığı esnasında hem Osmanlı Devleti tarafından hem de yabancı devletler tarafından çeşitli nişan ve madalyalar ile ödüllendirilmiştir. Bu çerçevede 25 Eylül 1886'da Papa XIII. Leo tarafından Saint Greguvar (Gregory) Nişanının Birinci Rütbesi verilmiştir. ${ }^{103} 16$ Haziran 1887 tarihinde ise İtalya Krallığı tarafından Corona d'Italia Nişanı'nın Birinci Rütbesi verilmiştir. ${ }^{104}$ Vasa Paşa, 1887 yılında Beyrut'ta İdare Meclisine Marunî üye seçimi esnasında Marunî Piskoposu Yusuf ve Fransa Konsolosunun halkı iğfal etmek için yapmış oldukları yayınlarına ve bununla birlikte hükümetin bölgede yapılacak olan yatırımlara onay vermediği yönündeki propagandalarına karşı çok ciddi bir mücadele sergilemiştir. Söz konusu yayınların tekzibi ve hükümetin bölgedeki nüfuzunun artırılmasına yönelik yapmış olduğu bu çalışmalarla saltanatın hukukunu ve menfaatini savunan Vasa Paşa'ya hem gayretini artırmak hem de sadakatinden dolayı padişahın yeni bir lütfu olmak üzere 10 Ekim 1887'de

\footnotetext{
${ }^{100}$ Spagnolo, a.g.e., s. 178-179.

${ }^{101}$ Akarli, a.g.e., s. 53.

102 Spagnolo, a.g.e., s. 177-178.

103 BOA, I.DH, 1002/79171, H. 26.12 .1303 (25 Eylül 1886); BOA, DH.SAİD.d, 1/236, 29.12.1241 (4 Ağustos 1826).

${ }^{104}$ BOA, I.DH, 1034/81418, H. 24.09.1304 (16 Haziran 1887); BOA, DH.SAIDD.d, 1/236, 29.12.1241 (4 Ağustos 1826).
} 


\section{KATOLIKK BİR OSMANLI BÜROKRATI VE ARNAVUT MILLLIYETÇİSI PAŞKO VASA \\ PAŞA (1852-1892)}

İmtiyaz Nişan-1 Füruğ-efşan'ının altın ve gümüş madalyaları verilmiştir. ${ }^{105} 24$ Mayıs 1889'da Birinci Rütbeden Nişan-1 Ali Osmanî verilmiştir. ${ }^{106}$ Daha önce 1862 yılında Rusya tarafından Saint Stanislaus Nişanının Üçüncü Rütbesiyle ödüllendirilen Vasa Paşa, 1 Temmuz 1889 tarihinde ise aynı nişanın Birinci Rütbesiyle ödüllendirilmiştir. ${ }^{107}$

\section{Arnavut Milliyetçiliğiyle İlgili Faaliyetleri}

Vasa Paşa, Naim, Abdül ve Sami Fraşeri kardeşlerin oluşturduğu entelektüel vatanseverler halkasına dâhildi. Çok sayıda Arnavutça eser kaleme almışsa da en bilinen eserlerinin başında 1878 ' de yazdığ 1 "Ah! Zavallı Arnavutluk" isimli şiiri gelmektedir. Şiir, Arnavutçu çevreler tarafından Arnavut millî edebiyatının en parlak örneklerinden biri olarak kabul edilmiştir. ${ }^{108}$ Arnavutların toplumsal hayatlarında dinin rolü hakkında yapılan değerlendirmelerde Arnavutlar arasında dinî bilincin azlığından ve inançlarının yüzeyselliğinden bahsedilirken Vasa, Arnavutçu bir ruh aşılamaya çalıştığı meşhur şiirinde şu dizeleri kaleme almıştır. ${ }^{109}$

Arnavutlar, kardeşlerinizi öldürüyorsunuz,

Yüz parçaya bölünmüşsünüz:

Bazıları, ben Hristiyan ’ım diğerleri ben Müslümanım, diyor

Kimisi, Türküm kimisi Latin'im diyor;

Kimisi Yunanım kimisi Slav'ım diyor;

Siz talihsizler, hepiniz kardeşsiniz!

Rahipler ve hocalar karıştırlyor akıllarınızı

Parçalamak için sizleri...

$\cdots$

Arnavutlar, uyanın uykudan!

Hepiniz kardeşler gibi birleşin tek bir inançta!

Kulak asmayın kiliselere, camilere,

Arnavutların dini Arnavutçuluktur! ${ }^{110}$

105 BOA, I.DH, 1050/82480, H. 22.01 .1305 (10 Ekim 1887); BOA, I.DH, 1057/82962, H. 05.02.1305 (23 Ekim 1887); BOA, DH.SAID.d, 1/236, 29.12.1241 (4 Ağustos 1826).

106 BOA, I.DH, 1137/88737, H. 13.09.1306 (13 May1s 1889); BOA, DH.SAID.d, 1/236, 29.12.1241 (4 Ağustos 1826); BOA, Y.PRK.BŞK, 12/44, H. 08.02 .1305 (16 Ocak 1888).

107 BOA, I.DH, 1142/89130, H. 03.11.1306 (1 Temmuz 1889); BOA, DH.SAID.d, 1/236, 29.12.1241 (4 Ağustos 1826).

${ }^{108}$ Derviş Hima, a.g.m., s. 109.

${ }^{109}$ Nathalie Clayer, Arnavut Milliyetçiliğinin Kökenleri Avrupa'da Çoğunluğu Müslüman Bir Ulusun Doğuşu, çev. Ali Berktay, 1. Bask1, Bilgi Üniversitesi Yay., İstanbul 2013, s. 29.

${ }^{110}$ Skendi, a.g.e., s. 169-170; Clayer, a.g.e., s. 29; Clayer, a.g.e., s. 220. 


\section{SAID OLGUN}

1869 y1lında İstanbul'da Arnavutça için bir alfabe belirlemek amaciyla Arnavut ileri gelenlerinden ve eğitimcilerinden bir "cemiyet- $i$ maarif" oluşturulmuştur. Cemiyetin amacı, Arnavutça için yeni bir alfabe oluşturmak, bir matbaa kurarak yayınlar çıkarmak ve okullar açmak olarak belirlenmiştir. ${ }^{111}$ İçerisinde Kristoforidhi, Girit eski valisi Mustafa Paşa Pojani, Tiranlı Süleyman Paşa, Tiranlı Said Bey Toptani, Leskovikli Rüstem Paşa, İsmail Kemal Bey Vlora, Kestoratlı Kristak Zografi ve Hasan Tahsin'in bulunduğu heyette Paşko Vasa da yer almıştır. Daha sonra Hasan Tahsin'in evinde devam eden toplantılara Jani Vreto, Tiranlı Said Bey, Ergiri/Gjirokasterli Şevki Efendi, Paramithialı Yahya Dino, Staroveli Hekim İbrahim Bey, Sami Bey Fraşeri, Kristoforidhi ve Paşko Vasa katılmışlardır. ${ }^{112}$ Toplantılarda yapılan müzakereler esnasında Vasa, Arnavutça için Latin alfabesinin kullanılmasını savunmuştur. O, Latin alfabesini savunurken eğitim seviyesi en yüksek olan Avrupalı milletlerce kullanılıyor olması, Arnavutların da Avrupalı oldukları ve Katolik Arnavutlarca yüzyıllardır kullanılıyor olduğu gibi argümanların yanı sıra Latin alfabesi ile yazılan kitapların Avrupa'da herhangi bir matbaada kolayca bastırılabilirken özel bir alfabe ile bunun mümkün olmayacağ 1 şeklinde daha pragmatik bir gerekçe ortaya koymuştur. Bu noktada Jani Vreto ve Kristoforidhi gibi isimler her sese bir harf ilkesine bağlı olarak özel sesler için iki harfin birleştirilmesi ilkesine karş1 çıkmış; Yunan ve Latin alfabesinden hareketle yeni bir alfabe geliştirilmesini ve bunun birkaç özel harfle tamamlanmasını istemişlerdir. $\mathrm{Bu}$ noktada Yunan alfabesini, Latin alfabesinin öncülü ve Yunanlıları Avrupa'da bilimin ve bilginin keşfinin ilk öncülleri olarak nitelendiren Jani Vreto'nun Ortodoks; Latin alfabesini savunan Vasa'nın Katolik olduğunu belirtmekte fayda var. ${ }^{113}$

1877-1878 Osmanl1-Rus Harbi, Arnavut milliyetçiliği için önemli bir dönüm noktası olmuştur. Savaş sonunda imzalanan 3 Mart 1878 tarihli Ayastefanos Antlaşması ile Arnavut topraklarının bir kısmının Bulgaristan, Sirbistan, Karadağ ve Yunanistan'a verilmesinin kararlaştırılması üzerine Vasa, aralarında Sami ve Abdül Fraşeri kardeşler ile Leskovikli Jani Vreto'nun bulunduğu bir grup Arnavut tarafindan "Arnavut Haklarını Savunma Komitesi"ni kurmuşlardır. ${ }^{114}$

\footnotetext{
${ }^{111}$ Mümeyyiz, N: 79, 8 Şaban 1286 (13 Kasım 1869).

112 Clayer, a.g.e., s. 170-171.

113 Clayer, a.g.e., s. 173; Skendi, a.g.e., s. 139.

${ }^{114}$ Nuray Bozbora, Osmanlı Yönetiminde Arnavutluk ve Arnavut Ulusçuluğu'nun Gelişimi, 1. Baskı, Boyut Kitapları, İstanbul 1997, s. 190; Kırmızı, a.g.t., s. 68; Bilgin Çelik, İttihatçılar ve Arnavutlar, 1. Baskı, Büke Kitapları, İstanbul, Ağustos 2004, s. 66.
} 


\section{KATOLIKK BİR OSMANLI BÜROKRATI VE ARNAVUT MILLLIYETÇİSI PAŞKO VASA \\ PAŞA (1852-1892)}

$\mathrm{Bu}$ dönemde İngiliz Elçiliğine takdim edilen memorandum Vasa tarafından kaleme alınmıştır. Vasa, Avrupalı diplomatlara seslenen bu ilk memorandumda genel olarak Arnavutluk sorununa ve Arnavutlara dikkat çekmeye çalışmıştır. Daha sonra İşkodra bölgesi olarak da nitelendirilebilecek olan Kuzeybatı bölgelerinin sorunları üzerinde durarak Ortodoks ve Slav bulunmayan bu toprakların din ve irk farklılığı nedeniyle Karadağ tarafından ilhak edilemeyeceğini savunmuştur. Osmanlı Devleti'ne yöneltilen tenkitlerde yasaların yetersizliği, kötü yönetim, askerî yetersizlikler ve buna bağlı olarak Arnavutların kendilerini müdafaaya mecbur kalmaları gibi konulara dikkat çekmiştir. Arnavutlara özerklik verilmesi ve Avrupa ailesine dâhil edilmeleri şeklindeki talebini şu şekilde ifade etmiştir: "Üstelik kendilerini Türkiye'ye bağlayan zincirleri kırmaya kararlı olan Arnavutlar, kendi arzulart ve gelenekleriyle daha uyumlu olacak, ayrı bir hükümet istiyorlar; ırkları ve yakınlıkları bakımından ait oldukları büyük Avrupa ailesine girme haklarını talep ediyorlar."115

Arnavut Haklarını Savunma Komitesi, Kuzey Arnavutluk'un merkezi kabul edilen Prizren'de ulusal bir kongrenin toplanmasına karar vermiştir. Alınan bu karara bağlı olarak 10 Haziran 1878'de 300 delegenin katılımıyla açılan Prizren Kongresi, Prizren Birliği'ne temel teşkil etmiştir. ${ }^{116}$ Prizren Birliği hem merkezden hem de İşkodra ve İstanbul şubelerinden Berlin Kongresi'ne katılan yabancı devletlere ve Babıâli'ye muhtıralar göndererek Birliğin amaçları hakkında bilgi verirken ${ }^{117}$ İstanbul'daki Arnavut Haklarını Savunma Komitesi de Prizren Birliği üyelerinden Vasa'nın kalemiyle 20 Haziran 1878'de İstanbul'da bulunan Avusturya-Macaristan İmparatorluğu Dışişleri Bakanı Kont Andrassy’ye bir muhtıra göndermiştir. Muhtırada özetle şunlar ifade edilmiştir: “Arnavut ulusu, Berlin Kongresi'ne kendi dileklerini sunarak, kendi bağrından koparılıp başka uluslara hediye edilmek istenen topraklarını ve diğer ulusal ve hayatî haklarını bizzat askerî güç ve olanakları ile savunmak üzere hazır ve nazır bulunduğunu bildirmek şerefine

\footnotetext{
115 Clayer, a.g.e., s. 195

${ }^{116}$ Bozbora, a.g.e., s. 190-191; Kırmızı, a.g.t., s. 68; Prizren Birliği hakkında ayrıntılı bilgi için bkz. Yüksel Çelik, Prizren İttihad Cemiyeti ve Faaliyetleri (1877-1881), Marmara Üniversitesi Türkiyat Araştırmaları Enstitüsü Yayımlanmamış Yüksek Lisans Tezi, Danışman: Doç. Dr. İdris Bostan, 1997.

117 Bozbora, a.g.e., s. 192.
} 


\section{SAID OLGUN}

naildir..." Bu ifadelerle topraklarını ve millî haklarını savunmak için silahlı mücadeleye kararlı olduklarını ortaya koymaya çalışmışlardır. ${ }^{118}$

1879 yılı başlarında Arnavut Halkının Haklarını Koruma Komitesi tarafindan aralarında Hasan Tahsin, Vasa Paşa, Jani Vreto, Koto Hoxhi ve Şemseddin Sami'nin bulunduğu beş kişilik bir heyet kurularak Arnavut alfabesi üzerinde çalışmaları sağlanmıştır. Heyet, Arnavutçanın hangi alfabe ile yazılması gerektiği konusunda çok yoğun bir çalışma yapmıştır. Nihayet Latin alfabesinin, Arnavutlar için doğrudan bir tehdit unsuruyla irtibatlı olmadığına karar verilmiştir. Heyet, 19 Mart 1879 tarihinde yapılan son toplantı neticesinde Şemseddin Sami tarafından hazırlanan ve "İstanbul Alfabesi" adıyla anılan alfabeyi Arnavutça için ortak alfabe olarak kabul etmiștir. İstanbul alfabesi, 1879 y1lında Arnavut Dilinin Alfabesi (Allfabetare e gjuhësë shqip) adıyla İstanbul'da basılan bir kitapta ilk kez kullanılmıştır. İlk on sayfasında İstanbul alfabesinin tanıtıldığı kitap, Şemseddin Sami, Vasa Paşa ve Jani Vreto tarafindan kaleme alınan okuma parçalarından oluşmuştur. Vasa Paşa, "Pelasglar Döneminden İskender Bey'e Kadar Arnavutluk'un Tarihçesi (1405-1468)" başlıklı bir okuma parçası kaleme almıştır. ${ }^{119}$

12 Ekim 1879 tarihinde İstanbul'da “Cemiyet- $i$ İlmiyye- $i$ Arnavudiyye" adıyla bir cemiyet kurulmuştur. Cemiyet, Arnavutça eserler basmak, haftada iki kez yayımlanan bir gazete neşretmek ve Arnavutluk'ta okullar açmak gibi amaçlara sahipti. Cemiyet, ilk kurulduğunda onu Müslüman, dördü İşkodralı Katolik ve on dördü de Ergiri ve Görice'den olmak üzere toplam yirmi sekiz üyeden meydana gelmiştir. Paşko Vasa, Noç Xhuxhi, Nikolla, Gjon Bonati, İbrahim Starova, Ferid Vlora, Mehmet Ali Vrioni, Prevezeli Veysel ve İbrahim Dino kardeşler, Abdül Frasheri, Şemseddin Sami Frasheri, Mustafa Yanya, Seyfullah Zavalani, Ergirili Ahmed Şevki gibi isimler cemiyet üyeleri arasında yer almışlardır. Cemiyetin ilk bastırdığı kitaplardan biri, Vasa Efendi'nin Fransızca yazılan daha sonra “A. D." tarafindan Türkçeye çevrilen “Arnavutluk ve Arnavutlar" isimli kitabı olmuştur. ${ }^{120}$

Tüm bu faaliyetlerinin yanı sıra Arnavutluk, Arnavutlar ve Arnavutça hakkında yapmış olduğu çalışma ve yayınlarıyla Vasa Paşa, Arnavut

\footnotetext{
118 Necip Alpan, Kuruluşunun 100. Yıldönümünde Prizren Birliği ve Arnavutlar, Çağdaş Basımevi, Ankara 1978, s. 52.

${ }^{119}$ Said Olgun, Arnavut Milliyetçiliğinin Gelişiminde Mektepler, Gece Kitaplı̆̆ı, Ankara 2015, s. 114.

${ }^{120}$ Olgun, a.g.e., s. 115-116.
} 


\section{KATOLIKK BİR OSMANLI BÜROKRATI VE ARNAVUT MILLLIYETÇİSI PAŞKO VASA \\ PAŞA (1852-1892)}

milliyetçiliğinin önemli figürlerinden biri olarak kabul edilmiştir. Öyle ki Prizren Birliği'nin 100. yıl dönümüne tekabül eden 1978 yılında Beyrut'taki mezarı açılarak cenazesi, doğduğu yer olan İşkodra'ya nakledilmiştir.

\section{Hastalığı, Vefatı ve Ailesi}

Bir süredir kalp rahatsızlığından mustarip olan 67 yaşındaki Vasa Paşa'nın hastalığı, 1892 yılının Mayıs ayına gelindiğinde daha da ilerlemiştir. Beyrut Valisi Avlonyalı İsmail Kemal Bey (1844-1919), İstanbul'a gönderdiği 4 Mayıs 1892 tarihli telgrafında gizli bir şekilde tabiplerden edindiği bilgiye göre Paşa'nın kalp krizi geçirdiğini, hastalığının diğer komplikasyonlarla birlikte hayatını tehdit ettiğini ifade etmiştir. ${ }^{121} 19$ Mayıs 1892 'de Suriye Valisi Osman Paşa ise Vasa Paşa'nın rahatsızlığından dolayı Cebel-i Lübnan'ın idaresinin damadı Kupilyan ile memurlardan birinin eline geçtiğini bundan dolayı da bölgede asayiş problemlerinin baş gösterdiğini, cinayet ve gasp olaylarında artış olduğunu, İngiliz yanlısı Şuf kaymakamının bu durumdan istifade ederek Müslüman, Hıristiyan ve Dürzîleri birbirlerine karşı kışkırttığını ifade ederek bunun önünün alınması için mutasarrıf sağlığına kavuşuncaya kadar yerine bir vekilin tayin edilmesi gerekliliğini ifade etmiştir. ${ }^{122}$

Vasa Paşa, hakkında kaleme alınan tüm bu yazılardan haberdarmışçasına 21 Mayıs'ta İstanbul'a gönderdiği yazısında geçirdiği rahatsızlığın çalışmasına mâni olacak bir boyutta olmadığını; işlerin bizzat kendisi tarafından sevk ve idare edildiğini; asayiş ve emniyetin berkemal olduğunu ve doktorların ifadesine göre birkaç güne kadar tüm sıkıntılarının sona ereceğini belirtmiştir. ${ }^{123}$

İsmail Kemal Bey, 28 Mayıs tarihli ikinci telgrafında Vasa Paşa'nın rahatsızlığının tedavi edilemeyecek noktaya geldiğini, açık bir şekilde ifade etmese de her an vefat edebileceğini; yönetimin iki memurun elinde kaldığına yönelik dedikoduların olduğunu bu yüzden hastalığı devam ettiği müddetçe mutasarrıflığın itimat edilir birine verilmesinin uygun olacağını belirtmiştir. ${ }^{124}$

\footnotetext{
${ }^{121}$ BOA, Yıldız Perakende Evrakı Umumi (Y.PRK.UM), 24/66, H. 06.10 .1309 (4 May1s 1892); BOA, Y.A.HUS, 259/47, H. 08.10.1309 (6 May1s 1892).

${ }^{122}$ BOA, A.MTZ.CL, 2/78, H. 26.11.1309 (22 Haziran 1892).

${ }^{123}$ BOA, Y.A.HUS, 260/124, H. 28.10.1309 (26 May1s 1892).

124 BOA, Y.PRK.UM, 24/93, H. 01.11.1309 (28 May1s 1892); BOA, Y.A.HUS, 261/22, H. 04.11.1309 (31 May1s 1892).
} 


\title{
SAIDD OLGUN
}

Vasa Paşa, her ne kadar birkaç gün içerisinde tamamen iyileşmiş olacağından ümitli olsa da öyle anlaşılıyor ki işler beklediği gibi ilerlememiştir. 11 Haziran'da hasta ve yaşlı mutasarrıf, tedavisi için doktorların tebdil-i hava önerisinde bulduklarını belirterek İstanbul'a gitmek için izin talebinde bulunmuştur. Bölgede herhangi bir asayiş probleminin olmaması göz önünde bulundurularak Lübnan'dan ayrılmasında bir mahzur görülmeyen Vasa Paşa'ya gerekli izin verilmiştir. ${ }^{125}$ Ancak Vasa Paşa, İstanbul'a hareket etmeye firsat bulamamıştır. Devlet adamlığının yanı sıra yapmış olduğu ilmi çalışmalarıyla da tanınan Paşa, 29 Haziran 1892 'de Beyrut'ta vefat etmiştir. ${ }^{126}$ etmiştir:

Beyrut Valisi İsmail Kemal Bey, yaşanan bu süreci şu şekilde ifade

\begin{abstract}
"Beyrut'ta iken, Lübnan valisi hemşehrim Vasa Paşa öldü. Kalp hastalı̆̆ vardl ve durumu ümit bırakmayacak şekilde gittikçe kötüleşiyordu. Lübnan valiliği önemli bir makam olduğundan, doktorla konuştuktan sonra, en iyisinin durumu Babıâli'ye bildirmek olacağından düşündüm ve öyle de yaptım. Sadrazam ise beni hayrete düşüren bir şey yaptı, mesajımı mahrem olarak değerlendirmek yerine, telgrafla Vasa Paşa'ya durumunu sormuş, sonra da bana kendisinden iyileşmekte olduğuna dair cevap aldığını bildirdi. Bir iki gün sonra zavallı adam öldü." 127
\end{abstract}

Vasa Paşa, 30 yaşında olduğu 1855 yılında ilk eşi Drande ile evlenmiştir. Bu evlilikten beş çocukları olan çift, dört çocuklarını çok erken yaşlarında kaybetmişlerdir. Drande'nin ölümünden sonra ikinci evliliğini Catherine Bonnati ile yapmışsa da o da Vasa Paşa'nın Cebel-i Lübnan mutasarrıflığına atanmasından çok kısa bir müddet sonra 1884 yılında tüberkülozdan vefat etmiştir. Drande ile evliliğinden geride kalan çocukları Rosa Kupelyan da tüberkülozdan ${ }^{128} 28$ yaşındayken 27 Ocak 1887'de

\footnotetext{
125 BOA, Y.EE, 104/111, H. 18.11 .1309 (14 Haziran 1892); BOA, I.MTZ.CL, 4/218, H. 18.11.1309 (14 Haziran 1892); BOA, I.MTZ.CL, 4/219, H. 18.11.1309 (14 Haziran 1892).

126 BOA, I.MTZ.CL, 7/304, H. 04.12.1309 (30 Haziran 1892); The Boston Guardian and Lincolnshire Independent, 30 July 1892; “Literature”, East Anglian Daily Times, 25 July 1892, s. 3; Sabah, 19 Haziran 1308 (2 Temmuz 1892), s. 1.

127 İsmail Kemal Bey'in Hattratı, s. 147.

${ }^{128}$ Elsie, Albanian Literature: A Short History, s. 82.
} 


\section{KATOLIKK BİR OSMANLI BÜROKRATI VE ARNAVUT MILLLIYETÇİSI PAŞKO VASA PAŞA (1852-1892)}

Beyrut'ta vefat etmiştir ${ }^{129}$. Üçüncü kez evlenen Vasa Paşa, son evliliğini Brett (?) Hanımla yapmış ve bu evlilikten Michel ve Leon isimlerinde iki oğlu olmuştur. Vasa Paşa'nın vefatı üzerine ailesinin İstanbul'a rahat bir şekilde dönmelerini sağlamak için "atiyye-i seniyyeden" 100 lira verilmesine karar verilmiştir. ${ }^{130}$ Bununla birlikte "Vasa Paşa'nın vefatına ailesinden gördüğü su-i muamelenin sebebiyet verdiği" konuşulduğu için aile İstanbul'a ulaştıktan sonra bağlanması gereken maaşın dışında müstesna bir muameleye tabi tutulmamaları da Padişah tarafından istenilmiştir. ${ }^{131}$ Bir müddet sonra ise eşine ve iki küçük oğluna toplamda 5976 kuruş maaş bağlanmıştır. ${ }^{132} 1908$ tarihli iki farklı belgede Vasa Paşa'nın Mekteb-i Sultani ve Mekteb-i Hukuk'tan mezun olan Selim isimli oğlunun kendisine uygun bir memuriyet talebinde bulunduğu ve II. Abdülhamid'in iradesiyle Tahrirat-1 Hariciye Kaleminde görevlendirildiği bilgisine yer verildiği görülmektedir. ${ }^{133}$

Vasa Paşa'yı Cebel-i Lübnan Mutasarrıflığı esnasında en fazla üzen hadise kızı Rosa'nın eşi damadı Kirkor Kupelyan Efendi ${ }^{134}$ hakkındaki iddialar olmuştur. Aynı zamanda Cebel-i Lübnan Aklam Müdürü olarak görev yapan Kupelyan hakkında çeşitli tarihlerde kaleme alınan şikâyet dilekçelerinde görevini kötüye kullandığı, rüşvet aldığı yönündeki iddialar ifade edilmiştir. ${ }^{135} \mathrm{Bu}$ çerçevede dile getirilen şikâyetlerde Kupelyan Efendi'nin kontrolü altındaki dairelerde rüşvetsiz iş yaptırmanın mümkün olmadığı, davaların en fazla rüşvet verenin lehine sonuçlandırıldığı, memurları çeşitli iftiralarla azlederek aldığı rüşvetle görevlerine dönmelerini sağladığı iddiaları oldukça dikkat çekicidir. ${ }^{136}$ Vasa Paşa, damadı hakkında dile getirilen iddiaların asılsız olduğu ve tüm bunların kendisinin göreve atanmasıyla birlikte menfaatlerini kaybedenler ile Fransa konsolosunun

129 BOA, Hariciye Nezâreti Londra Sefareti Belgeleri (HR.SFR.3), 333/12, Miladî (M.) 01.02.1887.

130 BOA, Y.A.HUS, 262/56, H. 17.12.1309 (13 Temmuz 1892).

131 BOA, BEO, 32/2363, H. 19.12 .1309 (15 Temmuz 1892); BOA, I.MTZ.CL, 7/307, H. 19.12.1309 (15 Temmuz 1892).

${ }^{132}$ BOA, BEO, 39/2902, H. 02.01.1310 (27 Temmuz 1892); BOA, SD, 917/89, 22.03 .1310 (14 Ekim 1892); BOA, DH.MKT, 2005/29, H. 03.03 .1310 (25 Eylül 1892).

133 BOA, BEO, 3367/252462, H. 24.06.1326 (24 Temmuz 1908); BOA, HR.TH, 366/37.

${ }^{134} 1892$ yılına kadar Cebel-i Lübnan Mutasarrıflı̆̆ı Aklam Müdürlüğü görevinde bulunmuştur. Salname-i Cebel-i Lübnan, 1. Defa, Beytüddin 1304 (1887), s. 33; Salname-i Cebel-i Lübnan, 2. Defa, Beytüddin 1305 (1888), s. 33; Salname-i Cebel-i Lübnan, 3. Defa, Beytüddin 1306 (1889), s. 33; Salname-i Cebel-i Lübnan, 4. Defa, Beytüddin 1307 (1890), s. 37; Salname-i Cebel-i Lübnan, 5. Defa, Beytüddin 1308 (1891), s. 43; Salname-i Cebel-i Lübnan, 6. Defa, Beytüddin 1309 (1882), s. 43.

${ }_{135}$ BOA, HR.TO, 530/26.

${ }^{136}$ BOA, I.MTZ.CL, 3/191, H. 10.01.1305 (28 Eylül 1887). 


\section{SAİD OLGUN}

iftiralarından ibaret olduğu görüşündedir. ${ }^{137}$ Cebel-i Lübnan'daki politik entrikaların ve rüşvet ağının mimarı olduğuna inanılan Kupelyan Efendi, 1887 yılının Kasım ayında kısa bir müddet Cebel-i Lübnan'dan uzaklaştırılmışsa da tekrar eski görevine dönmüştür. ${ }^{138}$

\section{Eserleri}

Vasa Paşa, aldığı eğitim, yaptığı görevler ve sahip olduğu siyasî ve ideolojik görüşlerine bağlı olarak birçok eser kaleme almıştır. Araştırma/inceleme, şiir, roman, hatırat ve ders kitabı türündeki bu çalışmalarından en bilineni, Türkçeye Arnavutluk ve Arnavutlar adıyla çevrilen La Vérité sur l'Albanie et les Albanais: Étude Historique et Critique olmuştur. Kitap ve makaleleriyle Arnavut tarihi, edebiyatı ve diline yapmış olduğu katkılar ona Arnavut milliyetçileri arasında önemli bir yer edinmesi imkânı sağlamıştır.

\section{a. La mia prigionia, episodic storico dell'assedio di Venezia}

1847-1849 y1lları arasında İtalya'da kalan Vasa, 1848 İhtilallerine bağlı olarak burada meydana gelen olayların içerisinde doğrudan doğruya yer almıştır. 1849 yılında İstanbul'a geldikten yaklaşık bir yıl sonra 1850 yılında La mia prigionia, episodic storico dell'assedio di Venezia (Tutukluluğum, Venedik Kuşatmasından Tarihi Bir Bölüm) adıyla anılarını yayımlamıştır. ${ }^{139}$

\section{Efendi}

\section{b. La Bosnie et L'Herzégovine pendant La Mission de Djevdet}

Vasa Efendi, 1865 yılında Fransızca olarak kaleme aldığ La Bosnie et L'Herzégovine pendant La Mission de Djevdet Efendi (Cevdet Efendi'nin Görevi Esnasında Bosna Hersek) isimli kitabında Cevdet Paşa'nın müfettişliği dönemindeki Bosna ve Hersek'in durumu ile Cevdet Paşa'nın uygulamaları hakkında bilgiler vermiştir. ${ }^{140}$

\footnotetext{
${ }^{137}$ BOA, Y.EE, 104/194, H. 23.02.1303 (1 Arallk 1885).

${ }^{138}$ Akarli, a.g.e., s. 54.

${ }^{139}$ Elise, kitabının İtalyan yazar Silvio Pellico (1789-1845)'nun Le mie Prigioni isimli eseriyle benzer bir başlık taşıdığına dikkat çeker. Elsie, Albanian Literature: A Short History, s. 81.

${ }^{140}$ Pasco Wassa Efendi, La Bosnie et L'Herzégovine pendant La Mission de Djevdet Efendi, Imprimerie du "Courrier d'Orient", Constantinople 1865.
} 


\section{KATOLIKK BİR OSMANLI BÜROKRATI VE ARNAVUT MILLIYYETÇİSI PAŞKO VASA \\ PAŞA (1852-1892)}

\section{l'Albanie}

c. Esquisse historique sur le Monténégro d'après les traditions de

Adını "Arnavut Geleneklerine Göre Karadağ'ın Tarihi Öyküsü" şeklinde Türkçeye çevirebileceğimiz bu eser, 1872 yılında Pasco Wasa imzasıyla İstanbul'da yayımlanmıştır. ${ }^{141}$

\section{ç. Rose e Spine}

"Güller ve Dikenler" isimli bu kitap, Vasa'nın İtalyanca olarak kaleme aldığ 1 aşk, 1 stırap ve yalnızlık temalı 41 şiirinden mürekkeptir. ${ }^{142}$ Vasa, 1873 yılında yayımlanan ve toplamda 1600 mısradan oluşan bu şiirlere, yaşadığı çeşitli aile trajedilerini yansıtmıştır. ${ }^{143}$

\section{d. L’alphabet latin appliqué à la langue albanaise}

“Arnavut Diline Uygulanan Latin Alfabesi” isimli bu eser, 1878 yılında imzasız olarak İstanbul'da 16 sayfa olarak basılan alfabe kitabıdır. ${ }^{144}$

\section{Critique}

e. La Vérité sur l'Albanie et les Albanais: Étude Historique et

Çalışma ilk olarak 1879 yılında İstanbul'da Fransızca olarak yayımlanmıştır. ${ }^{145}$ Daha sonra aynı yıl Fransa'nın başkenti Paris'te yeni bir baskısı yapılmıştır. ${ }^{146}$ Kapağında Vasa Efendi'nin "Hıristiyan Arnavut Devlet Memuru" şeklinde tanıtıldığı kitap, kısa süre içerisinde çok farklı dillere çevrilmiştir. Helenler ile Arnavutlar arasındaki farklılı̆̆ dayanarak ortaya koyan bu eserin Osmanl1-Yunan görüşmelerinde faydalı olabileceğini düşünen Paris'teki Osmanlı sefirinin girişimleriyle ${ }^{147}$ "The

\footnotetext{
${ }^{141}$ Pasco Wassa, Esquisse historique sur le Monténégro d'après les traditions de l'Albanie, Imprimerie du Courrier d'Orient, Constantinople 1872.

142 Robert Elsie, "The Hybrid Soil of the Balkans: A Topography of Albanian Literature", History of the Literary of East-Central Europe, Vol. II, Edited By: Marcel Cornis-Pope, John Neubauer, John Benjamins Publishing Company, Amsterdam/Philadelphia 2004, s. 294.

${ }^{143}$ Elsie, Albanian Literature..., s. 83.

${ }^{144}$ Pasco Wasa, L'alphabet latin appliqué à la langue albanaise, Imprimerie du Courrier d'Orient, Constantinople 1878.

${ }^{145}$ Clayer, a.g.e., s. 200-201.

146 Wassa Effendi, La Vérité sur l'Albanie et les Albanais: Étude Historique et Critique, Imprimerie de la société anonyme de publications périodiques, Paris 1879.

${ }^{147}$ Clayer, a.g.e., s. 200-201.
} 


\section{SAID OLGUN}

Truth on Albania and the Albanians: Historical and Critical Issues"148 başlığıyla Londra'da İngilizce; “Albanien und die Albanesen: Eine historischkritische Studie" ${ }^{149}$ başlığıyla Berlin'de Almanca olarak yayımlanmıştır.

1879 y1lında Edward Saint John Fairman tarafindan Fransızca aslından İngilizceye çevrilen kitap için çeşitli tanıtım yazıları kaleme alınmıştır. Naval \& Military Gazette isimli süreli yayının 11 Haziran 1879 tarihli nüshasında kitabın ilgi çekici bilgiler içerdiği bu yüzden dikkatle okunmaya değer olduğu ifade edilmiştir. ${ }^{150}$ Aynı süreli yayının 22 Ağustos 1883 tarihli nüshasında ise çeviriyi yapan Fairman'ın turistlere ve bilim insanlarına yeni bir alan açtığı; kitabı okuyanların el değmemiş imkânları ve doğal güzellikleri yerinde görmek için Arnavutluk'a gitmek için heveslenmeye başladıkları ifade edilmiştir. ${ }^{151}$

Kitap hakkındaki en ciddi tanıtım yazılarından biri The Globe'un 16 Haziran 1879 tarihli nüshasında yer almıştır. "Greeks and Albanians" başlıklı yazıda Osmanlı-Yunan sınırının düzenlendiği o günlerde kitabın yazarı ve işlediği konular üzerinde durmanın gerekliliği belirtildikten sonra Vasa Efendi hakkında kısa bir bilgi verilmiş ve kitabın tanıtımına geçilmiştir. Yazıda Vasa Efendi'nin özellikle Yunanlılar ile Arnavutlar arasındaki farklılıkları ortaya koyduğu; Arnavutlara hem Türk hem de Yunan memurlara asla güvenmemeleri telkininde bulunduğu ve Arnavutluk'un özerkliğinin talep edilmesi gerektiğini ifade ettiği belirtilmiştir. ${ }^{152}$

Kitap, Priştineli Ali Daniş ${ }^{153}$ tarafindan "Arnavutluk ve Arnavutlar" başlığıyla Türkçeye çevrilerek 1879/1880 yılında Vasa'nın da üyesi olduğu Cemiyet-i İlmiyye-i Arnavudiyye tarafından yayımlanmıştır. ${ }^{154}$

148 Wassa Effendi, The Truth on Albania and the Albanians: Historical and Critical Issues, Translation by Edward Saint John Fairman, National Press Agency, London 1879.

149 Wassa Effendi, Albanien und die Albanesen: Eine historisch-kritische Studie, Verlang von Julius Springer, Berlin 1879.

${ }^{150}$ Naval \& Military Gazette, 11 June 1879, s. 463.

${ }^{151}$ Naval \& Military Gazette, 22 August 1883, s. 142.

152 "Greeks and Albanians", The Globe, 16 June 1879, s. 1.

${ }^{153}$ Kitabın Türkçe nüshasında mütercimin ismi “A. D.” şeklinde kısaltılarak verilmiştir. Derviş Hima mütercimin "Priştine Hanedanından Ali Daniş" olduğunu ifade etmiştir. Derviş Hima, a.g.m., s. 109. Ali Daniş, Priştineli Abdurrahman Paşa'nın oğlu ve Başmabeyinci Nişli Mahmut Bey'in damadıdır. Ali Daniş, Şura-yı Devlet Bidayet Mahkemesi Müddeiumumiliği görevinde bulunmuştur. Kazım Yetiş, Yahya Kemal Hayatı, C. 1, İstanbul Fetih Cemiyeti Yay., İstanbul 1998, s. 93.

${ }^{154}$ Vasa Efendi, Arnavutluk ve Arnavutlar, çev. A. D. (Ali Daniş), Mihran Matbaası, İstanbul 1297 (1879/1880). Kitap hakkında yapılan iki ayrıntılı değerlendirme için bkz. Uğur Bahadır 


\section{f. Grammaire albanaise à l'usage de ceux qui désirent apprendre cette langue sans l'aide d'un maître}

"Arnavutça Dilbilgisi, Bir Öğretici Yardımı Olmadan Bu Dili Öğrenmek İsteyenler İçin” başlıklı bu kitap, editörlüğünü Reinhold Rost'un yaptığı Asya ve Avrupa dillerinin yalınlaştırılmış gramer kitapları serisinden oluşan Trübner Koleksiyonun 14. kitabı olarak yayımlanmıştır. Yazar adının P. W. rumuzuyla verildiği bu gramer kitabı, 1887 yılında Londra'da Fransızca olarak yayımlanmıştır. ${ }^{155}$

\section{g. Bardha de Témal, Scènes de la Vie Albanaise}

Vasa Paşa'nın Albanus Albano müstear ismiyle Cebel-i Lübnan mutasarrıflı̆̆ 1 esnasında 1890 yılında Paris'te Fransızca yayımlanan romanıdır. ${ }^{156}$ Kitap, her ne kadar Arnavutça yazılmamış olsa da Taaşşuk-1 Talat ve Fitnat'1n yazarı Arnavut asıllı Şemseddin Sami'den sonra bir Arnavut tarafindan yazılan ve yayımlanan Arnavut temalı en eski roman olma özelliğine sahiptir. ${ }^{157}$ Roman, 1842 y1lında İşkodra' da geçen eğlenceli bir aşk hikâyesi olmakla beraber, okuyucuyu Kuzey Arnavutluk'un örf ve adetleri hakkında bilgilendirmek gibi bir amaca da sahipti. ${ }^{158}$

\section{h. "The Pelasgi and Their Modern Descendants"}

Royal Society of Literature üyesi olan Vasa Paşa'nın aynı derneğin başkanı Patrick Colquhoun ile birlikte Asiatic Quartery Review'de yayımlamış oldukları makale serisidir. Yazarlar, çalışmanın birbirlerinden

Bayraktar, "Mythifying the Albanians: A Historiographical Discussion on Vasa Efendi's 'Albania and the Albanians"', Balkanologie [En ligne], Vol. XIII, no 1-2 | décembre 2011, mis en ligne le 04 janvier 2012, consulté le 12 octobre 2018. URL: http://journals.openedition.org/balkanologie/2272 (E.T.: 11.04.2019); Uğur Bahadır Bayraktar, Milliyetçilik ve Osmanlı Eleştirisi: Arnavut Vasa Efendi'nin Tarih Anlayışı”, Toplumsal Tarih, Nisan 2014, ss. 22-28.

${ }^{155}$ Paşko Vasa (P. W.), Grammaire albanaise à l'usage de ceux qui désirent apprendre cette langue sans l'aide d'un maître, Trübner \& Co. Ludgate Hill., London 1887.

156 Albanus Albano (Pasco Wassa), Bardha de Témal, Scènes de la Vie Albanaise, Albert Savine, Paris 1890.

${ }^{157}$ Elsie, a.g.m., s. 295.

${ }^{158}$ Elsie, Albanian Literature: A Short History, s. 83. George Gawrych, The Crescent and the Eagle: Ottoman Rule, Islam and the Albanians, 1874-1913, I. B. Tauris, London - New York 2006, s. 86. 


\section{SAID OLGUN}

habersiz farklı iki milliyete mensup araştırmacının eş zamanlı olarak aynı sonuçlara ulaştıkları araştırmalarının birleştirilmesiyle ortaya çıktığını ifade etmişlerdir. Makale ile tarihi, etnolojik ve filolojik olarak Arnavutların Pelasgların alt soyu olduklarını ve Truva'yı kuşatanların Pelasglar olduğunu ispatlamaya çalışmışlardır. ${ }^{159}$

\section{Sonuç}

Doğduğu topraklar ile Roma ve Venedik'te almış olduğu eğitimin bir sonucu olarak birçok dile hâkim olan Vasa, Osmanlı bürokrasisinde yadsınamaz derecede önemli görevlerde bulunmuştur. Yapmış olduğu tüm görevlerde liyakati ve sadakatiyle ön plana çıkmış buna bağlı olarak gösterdiği başarılar hem Osmanlı hem de yabancı devletler tarafından verilen nişan, rütbe ve madalyalarla takdir edilmiştir.

1883-1892 yılları arasında Cebel-i Lübnan Mutasarrıfı olarak görev yaptığı Lübnan'da Marunî-Dürzî çatışmasını ortadan kaldırarak başta Fransa olmak üzere yabancı devletlerin bölgeye müdahalesine son vermeye gayret göstermiştir. $\mathrm{Bu}$ aşamada bölgedeki cehaleti ve geri kalmışlığı ortadan kaldırmak için okullaşma oranının ve ulaşım imkânlarının artırılmasına büyük bir önem vermiştir.

Vasa Paşa, devlet adamlığının yanı sıra Arnavutlar hakkında yapmış olduğu ilmî çalışmaları ve kaleme aldığı edebî eserleriyle Arnavut millî kimliğinin inşası sürecinde aktif rol üstlenmiştir. Fransızca ve İtalyanca kaleme aldığı eserleriyle Avrupa kamuoyunun dikkatini, Berlin Kongresi'nde varlığı dahi tartışılan, Arnavutlara yöneltmeye gayret göstermiştir. Bunun bir

159 Pasco Wassa Pasha, Patrick Colquoun, "The Ancient Pelasgi and Their Descendants", Asiatic Quartery Review, Vol. I, January-April 1891, ss. 159-162; p. 430-437; Pasco Wassa Pasha, Patrick Colquoun, "The Ancient Pelasgi and Their Descendants", Asiatic Quartery Review, Vol. II, July-October 1891, s. 122-128, ss. 385-392; Pasco Wassa Pasha, Patrick Colquoun, "The Ancient Pelasgi and Their Descendants", Asiatic Quartery Review, Vol. III, January-April 1892, s. 208-215; ss. 447-462; Pasco Wassa Pasha, Patrick Colquoun, "The Ancient Pelasgi and Their Descendants", Asiatic Quartery Review, Vol. IV, July-October 1892, s. 165-180, s. 467478; Pasco Wassa Pasha, Patrick Colquoun, "The Ancient Pelasgi and Their Descendants", Asiatic Quartery Review, Vol. V, January-April 1893, s. 435-448; Pasco Wassa Pasha, Patrick Colquoun, "The Ancient Pelasgi and Their Descendants", Asiatic Quartery Review, Vol. VI, July-October 1893, s. 187-194; s. 435-444; Pasco Wassa Pasha, Patrick Colquoun, "The Ancient Pelasgi and Their Descendants", Asiatic Quartery Review, Vol. VII, January-April 1894, s. 177-185. 
neticesi olarak Arnavut milliyetçiliğinin en önemli isimlerinden biri olarak kabul edilmiştir.

\section{KAYNAKÇA}

\section{Devlet Arşivleri Başkanlığı Osmanlı Arşivi (BOA)}

Babıâli Evrak Odası (BEO)

Dahiliye Nezareti Mektubi Kalemi Evrakı (DH.MKT)

Dahiliye Nezâreti Sicill-i Ahval Komisyonu Defterleri (DH.SAIDd)

Dahiliye Nezareti Şifre Evrakı (DH.ŞFR)

Hariciye Nezâreti Londra Sefareti Belgeleri (HR.SFR.3)

Hariciye Nezareti Mektubi Kalemi Evrakı (HR.MKT)

Hariciye Nezareti Siyasi (HR.SYS)

Hariciye Nezâreti Tahrirât-1 Hariciye Odası (HR.TH)

Hariciye Nezâreti Tercüme Odası Belgeleri (HR.TO)

İrade Dâhiliye (İ.DH)

İrade Eyalet-i Mümtaze Cebel-i Lübnan (İ.MTZ.CL)

İrade Hariciye (İ.HR)

İrade Meclis-i Mahsus (İ.MMS)

İrade Meclis-i Vala (İ.MVL)

Sadâret Âmedî Kalemi Defterleri (A.AMD)

Sadaret Eyalet-i Mümtaze Cebel-i Lübnan Evrakı (A.MTZ.CL)

Sadaret Mektubi Kalemi Umum Vilayat Evrakı (A.MKT.UM)

Sadaret Mektubi Mühimme Kalemi Evrakı (A.MKT.MHM)

Şura-yı Devlet Evrakı (ŞD)

Taşra Evrakı Bosna Müfettişliği (TŞRBNM)

Yıldız Esas Evrakı (Y.EE)

Yıldız Perakende Evrakı Başkitabet Dairesi Maruzatı (Y.PRK.BŞK)

Yıldız Perakende Evrakı Umumi (Y.PRK.UM)

Y1ldız Sadaret Hususi Maruzat Evrakı (Y.A.HUS)

Yıldız Sadaret Resmi Maruzat Evrakı (Y.A.RES)

\section{Resmî Yayınlar}

Salname-i Cebel-i Lübnan, 1. Defa, Beytüddin 1304 (1887). 


\section{SAID OLGUN}

Salname-i Cebel-i Lübnan, 2. Defa, Beytüddin 1305 (1888).

Salname-i Cebel-i Lübnan, 3. Defa, Beytüddin 1306 (1889).

Salname-i Cebel-i Lübnan, 4. Defa, Beytüddin 1307 (1890).

Salname-i Cebel-i Lübnan, 5. Defa, Beytüddin 1308 (1891).

Salname-i Cebel-i Lübnan, 6. Defa, Beytüddin 1309 (1892).

\section{Gazeteler}

Dublin Daily Express

East Anglian Daily Times

Greenock Advertiser

Irish Times

London Evening Standard

Morning Post

Mümeyyiz

Naval \& Military Gazette

Pall Mall Gazette

Sabah

Shipping and Mercantile Gazette

St. James Gazette

The Ayr Advertiser or West Country and Galloway Journal

The Batch Chronicle

The Boston Guardian and Lincolnshire Independent

The Dundee Advertiser

The Evening Telegraph

The Globe

The Jersey Weekly Press and Independent

The Leeds Mercury

The Lincoln, Rutland and Stamford Mercury

The Manchester Courier and Lancashire General Advertiser

The Morning Post

The Standard

\section{Makale ve Kitaplar}

Ahmed Cevdet Paşa, Sultan Abdülhamid'e Arzlar (Ma'rûzât), Yay. Haz. Yusuf Halaçoğlu, 1. Baskı, Babıali Kültür Yayıncılığı, İstanbul 2010.

Ahmed Cevdet Paşa, Tezâkir, No. 13-20, Yay. Haz. Cavid Baysun, 3. Bask1, Türk Tarih Kurumu Yay., Ankara 1991. 
AKARLI, Engin Deniz, The Long Peace: Ottoman Lebanon 1861-1920, University of California Press, California 1993.

AKYILDIZ, Ali, Sürgün Sefir Sadullah Paşa, Türkiye İş Bankası Kültür Yay., 1. Bask1, İstanbul 2011.

Albanus Albano (Pasco Wassa), Bardha de Témal, Scènes de la Vie Albanaise, Albert Savine, Paris 1890.

ALPAN, Necip, Kuruluşunun 100. Yıldönümünde Prizren Birliği ve Arnavutlar, Çağdaş Basımevi, Ankara 1978.

BAYRAKTAR, Uğur Bahadır, "Milliyetçilik ve Osmanlı Eleştirisi: Arnavut Vasa Efendi'nin Tarih Anlayışı”, Toplumsal Tarih, S. 244 (Nisan 2014), ss. 22-28.

"Mythifying the Albanians: A Historiographical Discussion on Vasa Efendi's 'Albania and the Albanians", Balkanologie [En ligne], Vol. XIII, no 1-2 | décembre 2011, mis en ligne le 04 janvier 2012, consulté le 12 octobre 2018. URL: http://journals.openedition.org/balkanologie/2272 (E.T. 11.04.2019).

BOZBORA, Nuray, Osmanl Yönetiminde Arnavutluk ve Arnavut Ulusçuluğu'nun Gelişimi, 1. Baskı, Boyut Kitapları, İstanbul 1997.

CLAYER, Nathalie, Arnavut Milliyetçiliğinin Kökenleri Avrupa'da Çoğunluğu Müslüman Bir Ulusun Doğuşu, çev. Ali Berktay, 1. Baskı, Bilgi Üniversitesi Yay., İstanbul 2013.

ÇELIK, Bilgin, İttihatçılar ve Arnavutlar, 1. Baskı, Büke Kitapları, İstanbul, Ağustos 2004.

ÇELIK, Yüksel, Prizren İttihad Cemiyeti ve Faaliyetleri (1877-1881), Marmara Üniversitesi Türkiyat Araştırmaları Enstitüsü, Yayımlanmamış Yüksek Lisans Tezi, Danışman: Doç. Dr. İdris Bostan, 1997.

DADYAN, Saro, "1861 Cebel-i Lübnan Nizamnamesi ve Özerk Cebel-i Lübnan'ın İlk Mutasarrıfı Garabed Artin Davud Paşa", Toplumsal Tarih, S. 239 (Kasim 2013), s. 22-26. 


\section{SAIDD OLGUN}

Derviş Hima, Musavver Arnavut, Matbaa-i Şems, İstanbul 1327 (1910), s. 108-109.

ELSIE, Robert, "The Hybrid Soil of the Balkans: A Topography of Albanian Literature", History of the Literary of East-Central Europe, Vol. II, Edited By: Marcel Cornis-Pope, John Neubauer, John Benjamins Publishing Company, Amsterdam-Philadelphia 2004, pp. 283-301.

2005 . , Albanian Literature: A Short History, I. B. Tauris, New York Historical Dictionary of Albania, The Scarecrow Press, Lanham 2010.

FINDLEY, Carter V., Osmanl Imparatorluğu'nda Bürokratik Reform Babıâli, 1789-1922, çev. Ercan Ertürk, Tarih Vakfi Yurt Yay., İstanbul 2014.

Gabriel Effendi Noradounghian, Recueil d'Actes Internationaux de L'Empire Ottoman, C. IV, Librairie Catillan, Paris 1897.

GAWRYCH, George, The Crescent and the Eagle: Ottoman Rule, Islam and the Albanians, 1874-1913, I. B. Tauris, London - New York 2006.

GÖLEN, Zafer, "Karadağ Devleti'nin Doğuşu: Osmanl1-Karadağ Sınır Tespiti (1858-60)", Belleten, C. LXXVIII, S. 282, Ağustos 2014, s. 659-698.

İsmail Kemal Bey'in Hatıratı, Ed.: Sommerville Story, çev. Adnan İslamoğulları, Rubin Hoxha, Tarih Vakfi Yurt Yayınları, İstanbul 2007.

KIRMIZI, Abdülhamit, II. Abdülhamit Dönemi (1876-1909) Osmanlı Bürokrasisinde Gayrimüslimler, Hacettepe Üniversitesi Sosyal Bilimler Enstitüsü, Yayımlanmamış Yüksek Lisans Tezi, Danışman: Prof. Dr. Bahattin Yediyıldız, Ankara 1998.

KÜLÇE, Süleyman, Osmanlı Tarihinde Arnavutluk, Yeni Asır Matbaası, İzmir 1944.

OLGUN, Said, Arnavut Milliyetçiliğinin Gelişiminde Mektepler, Gece Kitaplığı, Ankara 2015. 


\section{KATOLIKK BİR OSMANLI BÜROKRATI VE ARNAVUT MILLLIYETÇİSI PAŞKO VASA \\ PAŞA (1852-1892)}

Osmanlı Arşiv Belgelerinde Arnavutluk, Yay. Haz. H. Yıldırım Ağanoğlu, vd., Başbakanlık Devlet Arşivleri Genel Müdürlügü Yay., İstanbul 2008.

Pasco Vasa (P. W.), Grammaire albanaise à l'usage de ceux qui désirent apprendre cette langue sans l'aide d'un maître, Trübner \& Co. Ludgate Hill., London 1887.

Pasco Wasa, L'alphabet latin appliqué à la langue albanaise, Imprimerie du Courrier d'Orient, Constantinople 1878.

Pasco Wassa Efendi, La Bosnie et L'Herzégovine pendant La Mission de Djevdet Efendi, Imprimerie du "Courrier d'Orient", Constantinople 1865.

Pasco Wassa, Esquisse historique sur le Monténégro d'après les traditions de l'Albanie, Imprimerie du Courrier d'Orient, Constantinople 1872.

Pasco Wassa Pasha, Patrick Colquoun, "The Ancient Pelasgi and Their Descendants", Asiatic Quartery Review, Vol. I, January-April 1891, pp. 159162; pp. 430-437.

Pasco Wassa Pasha, Patrick Colquoun, "The Ancient Pelasgi and Their Descendants", Asiatic Quartery Review, Vol. II, July-October 1891, pp. 122128; pp. 385-392.

Pasco Wassa Pasha, Patrick Colquoun, "The Ancient Pelasgi and Their Descendants", Asiatic Quartery Review, Vol. III, January-April 1892, pp. 208-215; pp. 447-462.

Pasco Wassa Pasha, Patrick Colquoun, "The Ancient Pelasgi and Their Descendants", Asiatic Quartery Review, Vol. IV, July-October 1892, pp. 165180; pp. 467-478.

Pasco Wassa Pasha, Patrick Colquoun, "The Ancient Pelasgi and Their Descendants", Asiatic Quartery Review, Vol. V, January-April 1893, pp. 435448.

Pasco Wassa Pasha, Patrick Colquoun, "The Ancient Pelasgi and Their Descendants", Asiatic Quartery Review, Vol. VI, July-October 1893, pp. 187194; pp. 435-444. 


\section{SAIDD OLGUN}

Pasco Wassa Pasha, Patrick Colquoun, "The Ancient Pelasgi and Their Descendants", Asiatic Quartery Review, Vol. VII, January-April 1894, pp. 177-185.

REINKOWSKI, Maurus, Düzenin Şeyleri, Tanzimat'ın Kelimeleri, çev. Çiğdem Canan Dikmen, Yapı Kredi Yayınları, İstanbul 2017.

SERTOĞLU, Midhat, Mufassal Osmanlı Tarihi, C. VI, 1. Baskı, Türk Tarih Kurumu Yay., Ankara 2011.

SKENDI, Stavro, The Albanian National Awakening 1878-1912, Princeton University Press, Princeton (New Jersey) 1967.

SPAGNOLO, John P., France \& Ottoman Lebanon 1861-1914, Ithaca Press, London 1977.

ÜNSAL, Can, Rüstem Paşa'nın Mutasarrıflı̆g Döneminde Cebel-i Lübnan (1873-1883), Eskişehir Osmangazi Üniversitesi Yayımlanmamış Yüksek Lisans Tezi, Danışman: Yrd. Doç. Dr. Musa Kılıç, Eskişehir 2017.

Vasa Efendi, Arnavutluk ve Arnavutlar, çev. A. D. (Ali Daniş), Mihran Matbaas1, İstanbul 1297 (1879/1880).

Wassa Effendi, Albanien und die Albanesen: Eine historisch-kritische Studie, Verlang von Julius Springer, Berlin 1879.

Wassa Effendi, La Vérité sur l'Albanie et les Albanais: Étude Historique et Critique, Imprimerie de la société anonyme de publications périodiques, Paris 1879.

Wassa Effendi, The Truth on Albania and the Albanians: Historical and Critical Issues, Translation by Edward Saint John Fairman, National Press Agency, London 1879.

YETİŞ, Kazım, Yahya Kemal Hayatı, C. 1, İstanbul Fetih Cemiyeti Yay., İstanbul 1998. 